Canadian Science Publishing

Canadian Journal of Earth Sciences Revue canadienne des sciences de la Terre

\title{
A new elasmobranch assemblage from the early Eocene (Ypresian) Fishburne Formation of Berkeley County, South Carolina, USA
}

\begin{tabular}{|r|l|}
\hline Journal: & Canadian Journal of Earth Sciences \\
\hline Manuscript ID & cjes-2015-0061.R1 \\
\hline Manuscript Type: & Article \\
\hline Date Submitted by the Author: & $30-$ Aug-2015 \\
\hline Complete List of Authors: & $\begin{array}{l}\text { Case, Gerard R.; P.O. Box 664, } \\
\text { Cook, Todd D.; University of Alberta } \\
\text { Wilson, Mark V. H.; University of Alberta, Biological Sciences }\end{array}$ \\
\hline Keyword: & Elasmobranch, Eocene, Ypresian, Palaeobiogeography, Palaeoecology \\
\hline
\end{tabular}

SCHOLARONE ${ }^{m}$

Manuscripts 


\title{
A new elasmobranch assemblage from the early Eocene (Ypresian) Fishburne Formation of Berkeley County, South Carolina, USA
}

\author{
Gerard R. Case, Todd D. Cook, and Mark V. H. Wilson
}

Gerard R. Case. ${ }^{1}$ P.O. Box 664, Little River, SC 29566, USA, fosshark@sccoast.net Todd D. Cook. School of Science, Penn State Erie, The Behrend College, 4205 College Drive, Erie, PA, 16563, USA tdc15@psu.edu

Mark V. H. Wilson. Department of Biological Sciences, University of Alberta, Edmonton, AB, T6G 2E9, Canada; mark.wilson@ualberta.ca.

${ }^{1}$ Corresponding author. 


\title{
A new elasmobranch assemblage from the early Eocene (Ypresian) Fishburne Formation of Berkeley County, South Carolina, USA
}

\author{
Gerard R. Case, Todd D. Cook, and Mark V. H. Wilson
}

\begin{abstract}
A rich elasmobranch assemblage was recovered from the early Eocene (Ypresian) Fishburne Formation in a limestone quarry at Jamestown, Berkeley County, South Carolina, USA. Reported herein are 22 species belonging to eight orders, at least 15 families, and 21 genera. It includes the first occurrence of Protoginglymostoma from North America. Many of the reported species have large palaeobiogeographical ranges and inhabited waters on both sides of the Atlantic, whereas others endemic to the east coast of North America. The paucity of sizeable dentition from several of the larger species in this assemblage, and the apparent absence of relatively large macrophagous species found in contemporaneous deposits elsewhere, suggests the Jamestown site may represent a nursery ground and refuge for young and smaller individuals.
\end{abstract}

Key Words: Elasmobranch, Eocene, Ypresian, Palaeobiogeography, Palaeoecology 


\section{Introduction}

Late Cretaceous and Paleogene elasmobranch (shark and ray) assemblages have been recovered from numerous marine deposits along the Atlantic and Gulf coastal plains of the USA. Herein, we describe a rich assemblage that was recovered from the early Eocene (Ypresian) Fishburne Formation in a limestone quarry near the town of Jamestown, Berkeley County, South Carolina (Fig. 1). Palaeoichthyological specimens from this locality have been previously acknowledged in the literature. Cicimurri and Knight (2009) reported the teleostean fish Fisherichthys folmeri Weems, 1999 and Knight et al. (2007) reported the first occurrence of Eotorpedo White, 1934 from the Western Hemisphere in their description of E. hilgendorfi (Jaekel, 1904). More recently, Case et al. (2011) compiled a preliminary faunal list of the elasmobranch fossils recovered from the Jamestown site.

The purpose of this study is to provide a detailed account of the Jamestown taxa, which in turn, complements the growing body of Paleogene elasmobranch studies focusing on the Atlantic and Gulf coastal plains. A faunal comparison with species reported from other contemporary deposits outside of North America provides important palaeoecological and palaeobiogeographical insights for the species found in the assemblage.

\section{Geology}

A large assemblage of fossil fish remains was recovered from the Jamestown Limestone Quarry (managed by the Martin-Marietta Aggregate Company) near the town 
of Jamestown in Berkeley County, South Carolina, USA. The geology of the region has been extensively discussed in the literature (see Weems and Bybell 1998; Willoughby et al. 1999; Edwards et al. 2000). The material described herein was recovered from the Fishburne Formation, which is usually included as the upper formation in the PaleoceneEocene Black Mingo Group. The Fishburne Formation is a relatively thin, clay-rich, bioturbated, biomicrite limestone unit that dips gently to the southeast and underlies, in subsurface, approximately the southwestern half of the area shown in Fig. 1 (Gohn et al. 1983). The formation unconformably overlies sandstones of the Williamsburg Formation and underlies limestone of the Moultrie Member of the Santee Formation. It contains fragmented molluscan material and abundant microfossils (e.g., ostracodes and benthic foraminifers) indicating an early Eocene age (Edwards et al. 2000).

As mentioned above, the torpedo ray Eotorpedo hilgendorfi was first reported from this quarry by Knight et al. (2007). They noted that the material was recovered from the unit that underlies the middle Eocene Moultrie Member. Associated with $E$. hilgendorfi were teeth of the myliobatoid ray Meridiania convexa Case, 1994, which supports an early Eocene age, as the latter species is known only from Ypresian deposits (Knight et al. 2007). It should be noted that the quarry is now water filled and inaccessible (Knight et al. 2007; Cicimurri and Knight 2009).

\section{Materials and methods}

The specimens described herein were collected via the bulk sampling of spoil piles that were excavated from Pit III (now filled with water as Pond III) of the Jamestown Limestone Quarry (33 $16^{\prime} 32^{\prime}$ N, $79^{\circ} 38^{\prime} 40^{\prime}$ W). The material was 
processed using a \#20 U.S.A. standard testing sieve (A.S.T.M. E-11 specification) and the recovered teeth were immersed in a buffered $10 \%$ acetic acid solution to dissolve any remnants of matrix. Images were produced using a Jeol Field Emission Scanning Electron Microscope (JSM-6301 FXV). The material is catalogued in the collections of the University of Alberta Laboratory for Vertebrate Palaeontology (UALVP). Terminology largely follows that of Cappetta (2012).

\section{Systematic Palaeontology}

Class Chondrichthyes Huxley, 1880

Subclass Elasmobranchii Bonaparte, 1838

Cohort Euselachii Hay, 1902

Subcohort Neoselachii Compagno, 1977

Superorder Squalomorphi Compagno, 1973

Order Squatiniformes Compagno, 1973

Family Squatinidae Bonaparte, 1838

Genus Squatina Duméril, 1806

Squatina sp.

(Fig. 2.1)

Referred material: UALVP 55670, complete lateral tooth.

Description: The tooth contains a narrow median cusp that is slightly distally inclined and lingually directed. Both labial and lingual faces are convex and smooth. A round labial apron is present. A distinct cutting edge runs continuously across the median cusp and a pair of elongated heels. The mesial heel is obliquely directed, whereas the distal heel is 
relatively horizontal and bears an incipient cusplet. The lingual protuberance is welldeveloped. The basal face of the hemiaulacorhizous root is broad and more or less triangular. A central nutrient foramen is present.

Remarks: Squatina prima has been reported from early-middle Eocene deposits of Europe (Casier 1966; Bor 1985; Adnet 2006), central Asia (Case et al. 1996, as S. cf. prima), and northern Africa (Arambourg 1952; Noubhani and Cappetta 1997). North American reports include Virginia (Ward and Wiest 1990; Kent 1999a) and Georgia (Case 1981; Parmley and Cicimurri 2003). The overall morphology of UALVP 55670 is similar to that of Squatina prima (Winkler, 1876), with the exception of the incipient cusplet on the distal heel. Cappetta (2012) noted that identification of Squatina to species level is problematic given the conservative nature of the dentition. As such, we cautiously identify UALVP 55670 as Squatina sp.

Superorder Galeomorphi Compagno, 1973

Order Heterodontiformes Berg, 1937

Family Heterodontidae Gray, 1851

Genus Heterodontus Blainville, 1816

Heterodontus cf. H. sowasheense Case, 1994

(Fig. 2.2 and 2.3)

Referred material: UALVP 55671, fractured anterior tooth; UALVP 55672, complete lateral tooth.

Description: The anterior tooth bears a broad and relatively tall median cusp with a blunt apex. A pair of well-developed and divergent lateral cusplets flanks the median cusp. 
Lateral to the cusplets is a second pair of incipient cusplets. A distinct cutting edge runs continuously across the cusp and cusplets. The labial crown face is slightly convex and extends basally to form a broad apron that has distinct enameloid folding and a slightly concave edge. The lingual crown face is smooth and contains a well-developed lingual protuberance. Although a portion of the hemiaulacorhizous root has been fractured, it is apparent that the lobes are long and narrow and converge lingually to form a 'V-shaped' contour in basal view. In addition to a large central foramen, a lingual foramen and a pair of margino-lingual foramina are present.

The lateral tooth is mesiodistally elongated and labiolingually narrow. The crown is dome-like and contains a smooth transverse ridge. This ridge divides the occlusal face into a lingual region containing perpendicular enameloid ridges that extend to the crown edge. Many of the ridges bifurcate and produce distinct depressions. The labial region consists of reticulated enameloid that form numerous alveoli. The low root is hemiaulacorhizous.

Remarks: Ontogenetic heterodonty is well known in both extant and extinct species of Heterodontus (Reif 1976; Cappetta 2012). Adnet (2006) noted that the adult anterior teeth of the early Eocene species $H$. vincenti (Leriche, 1905) have rather short and rounded median cusps and reduced lateral cusplets, whereas cusplets in the juvenile form are well developed and often divided. Accordingly, the morphology of UALVP 55671 suggests it is likely from a young individual.

UALVP 55671 most closely resembles juvenile teeth described as Heterodontus sowasheense Case, 1994 from the Ypresian of Mississippi (compare with Case 1994, pl. 2, figs. 19-23 and 29-33). However, the Jamestown specimen has a slightly taller median 
cusp and an apron with an edge that is less concave and bears stronger enameloid folding. As such, we conservatively report this specimen as $H$. cf. $H$. sowasheense. The enameloid ornamentation of UALVP 55672 also largely conforms to the lateral tooth ornamentation of H. sowasheense (compare with Case 1994, pl. 2, fig. 15).

The median cusp and lateral cusplets of the adult anterior teeth of $H$. sowasheensis from Mississippi (Case 1994) are considerably more developed than those of $H$. vincenti, originally described from the Lutetian of Belgium (Leriche 1905). The relatively tall median cusp and the presence of two pairs of lateral cusplets of UALVP 55671 bear more resemblance to anterior teeth of $H$. wardenensis Casier, 1966, from the Ypresian of England. However, the primary cusplets of the latter are less divergent than those of the Jamestown specimen and the secondary cusplets are more robust. Given that H. wardenensis is found in contemporaneous deposits with $H$. vincenti and that the overall tooth size of the former is noticeably smaller (compare Casier 1966, pl. 3, figure, 1 and 4), it is plausible that $H$. wardenensis may actually represent the juvenile form of H. vincenti.

Additional Heterodontus species have been reported from Eocene deposits along the Atlantic Coastal Plain of North America. Heterodontus pineti Case, 1981, reported from the Late Eocene of Georgia, can be easily distinguished from H. sowasheense by the absence of enameloid folding (compare with Case 1981, pl. 1, fig. 1a-d). An anterior tooth reported as $H$. lerichei Casier, 1943, from the early Eocene of Virginia (Kent 1999a, pl. 33K) has a median cusp that is taller and a single pair of lateral cusplets that are considerably less developed than those of $H$. sowasheense. Heterodontus lerichei was 
originally described from the teeth recovered from the late Thanetian of Belgium (Casier 1943).

\section{Heterodontus sp.}

(Fig. 2.4)

Referred material: UALVP 55673, fractured lateral tooth.

Description: The lateral tooth is mesiodistally elongated and labiolingually narrow. The crown is dome-like and has flat labial and lingual faces. No transverse ridge is apparent and the occlusal face bears enameloid folding that runs perpendicularly between the labial and lingual faces. The root is mostly fractured.

Remarks: UALVP 55673 can be differentiated from Heterodontus cf. sowasheense by its pattern of enameloid folding and distinctly flat labial and lingual crown faces. Given the poor preservation, we conservatively leave this specimen in open nomenclature.

Order Orectolobiformes Compagno, 1973

Family Ginglymostomatidae Gill, 1862

Genus Nebrius Rüppell, 1837

Nebrius thielensis (Winkler, 1874)

(Fig. 2.5 and 2.6)

Referred material: UALVP 55674 fractured anterolateral tooth; UALVP 55675, fractured lateral tooth.

Description: Anterolateral and lateral teeth have a broad asymmetrical crown. The distally inclined median cusp of the anterolateral tooth is only slightly larger than the 
multiple lateral cusplets that flank it. There are more lateral cusplets mesial to the median cusp than distal. A distinct cutting edge runs continuously across the cusp and cusplets. The labial crown face is convex and expands basally as a well-developed apron. The edge of the apron is strongly convex in one of the specimens and partially eroded in the other. The lingual crown face is also convex. The root is highly eroded in both specimens. Remarks: The single extant species of Nebrius inhabits tropical continental and insular Indo-Pacific waters (Compagno 2001); however, the fossil record, which extends to the Maastrichtian, reveals that this taxon was once more diverse and found in Atlantic waters (see Cappetta 2006; 2012).

Nebrius thielensis has been reported in early and middle Eocene deposits of Europe (Winkler 1874; Kemp et al. 1990). In North America, it has been recovered from Virginia (Kent 1999a; Müller 1999), North Carolina (Case and Borodin 2000), Georgia (Case 1981, as Ginglymostoma obliquus; Parmley and Cicimurri 2003), and Mississippi (Case 1994). Although the root of UALVP 55674 and 55675 is highly eroded, it is apparent that the labial root face is considerably more concave that of $N$. obliquus (Leidy, 1877), originally described from the Eocene of New Jersey. This character, along with a labial crown face that is more concave and an apron that is never bifid, differentiates $N$. obliquus from N. thielensis (Noubhani and Cappetta 1997).

Genus Protoginglymostoma Herman, 1977b

Protoginglymostoma ypresiensis Herman, 1977b

(Fig. 3.1)

Referred material: UALVP 55676, slightly fractured tooth. 
Description: The tooth bears a lingually directed median cusp with slightly concave cutting edges producing a relatively sharp apex. The cutting edges extend across a pair of reduced lateral cusplets and a second pair of incipient cusplets. The slightly convex labial crown face bears strong enameloid folding and forms a broad apron with an edge that is slightly eroded but clearly bifid. The smooth lingual crown face is convex and contains a well-developed lingual protuberance that has been partially eroded. The slightly damaged hemiaulacorhizous root is 'heart-shaped' in basal view. There is a large central foramen and a pair of large margino-lingual foramina.

Remarks: Cappetta (2006) reported Protoginglymostoma bighornensis (Case, 1987) and P. estesi (Herman, 1977a) from Cretaceous North America deposits; however, it has since been suggested that both species likely belong to Cantioscyllium (Cappetta 2012). As such, UALVP 55676 represents the first occurrence of the genus Protoginglymostoma outside of Belgium (Casier 1946; Herman 1977b) and Morocco (Tabuce et al. 2005, as Protoginglymostoma sp.) and represents a significant geographical expansion for this species.

Family Hemiscylliidae Gill, 1862

Genus Hemiscyllium Müller and Henle, 1838

Hemiscyllium sp. Herman, 1977b

(Fig. 3.2 and 3.3)

Referred material: UALVP 55677, slightly fractured anterior tooth; UALVP 55678, lateral tooth. 
Description: Teeth with a broad and robust median cusp. The apex is blunt and lingually directed. Both labial and lingual crown faces are convex and smooth. The median cusp of the anterior tooth is shorter than that of the lateral tooth. The wide labial apron overhangs the labial face of the root and is slightly bifid in the anterior tooth and convex in the lateral tooth. A distinct cutting edge runs continuously across the median cusp and a pair of rather low lateral cusplets. The lingual protuberance is well developed. The basal face of the holaulacorhizous root is heart-shaped. A large central nutrient foramen is situated within a nutrient groove that separates the root lobes. A pair of large margino-lingual foramina is also present.

Remarks: There are nine reported extant Hemiscyllium species, all of which are relatively small nectobenthic sharks that are endemic to Australia, New Guinea, Solomon Islands, and Indonesia (Allen et al. 2013) and have very low vagility (Musick et al. 2004).

Multiple extinct species of Hemiscyllium have been reported from deposits as old as the Late Cretaceous (Cappetta 2012). In contrast to the present-day distribution of Hemiscyllium, the palaeodistribution was considerably more widespread as the genus has been reported from Europe (e.g., Adnet 2006; Herman 1977a, 1982; Kriwet et al. 2007; Müller 1989; Müller and Diedrich 1991), southern Asia (Kumar et al. 2007), and northern Africa (Noubhani and Cappetta 1997). Two teeth have also been reported from the Campanian of Mississippi (Case 1991) and the Maastrichtian of New Jersey (Case 1995); however, given their fragmentary condition, these specimens were left in open nomenclature.

The overall morphology of the Jamestown specimens somewhat resembles Hemiscyllium bruxelliensis (Herman 1977b) originally described from the Lutetian of 
Belgium. However, UALVP 55677 has a slightly shorter median cusp compared to the anterior tooth designated as the holotype of H. bruxelliensis (see Herman 1977b, pl. figs. 2a-f) and the apron of UALVP 55678 is not bifid and is more prominent. Given the low vagility of extant Hemiscyllium spp. (Musick et al. 2004), it is likely that the Jamestown and Belgium material are not conspecific.

Family Rhinocodontidae Garmen, 1913

Genus Palaeorhincodon Herman, 1974

Palaeorhincodon sp.

(Fig. 3.4)

Referred material: UALVP 55679, fractured tooth.

Description: The tooth is somewhat mesiodistally compressed and labiolingually elongated. The high crown is strongly lingually directed and bears a distinct cutting edge. The rather robust median cusp is flanked by a pair of reduced lateral cusplets, one of which has been fractured. The smooth labial crown face is strongly convex and forms an apron. The lingual crown face is also smooth and strongly convex. The root has a welldeveloped lingual protuberance but is considerably eroded.

Remarks: The species Palaeorhincodon wardi Herman, 1974, has been reported from the Eocene of Europe (Herman 1974; Bor 1985; Adnet 2006), central Asia (Case et al. 1996), and western Africa (Cappetta and Traverse 1988). In North America, this species was reported from the early Eocene of Virginia (Kent 1999a). Noubhani and Cappetta (1997) described $P$. dartevellei from the Ypresian of Morocco. They noted that the teeth of this species differ from those of $P$. wardi by having a more prominent apron, more developed 
lateral cusplets, and a root with a median lingual canal that is often closed. UALVP 55679 does have an apron of similar prominence to that of $P$. dartevellei. Unfortunately, one lateral cusplet and much of the root have been eroded; thus we conservatively leave this specimen in open nomenclature. Parmley and Cicimurri (2003) also reported a single tooth of Palaeorhincodon sp. from the late Eocene of Georgia.

Order Lamniformes Berg, 1958

Family Odontaspididae Müller and Henle, 1839

Genus Brachycarcharias Cappetta and Nolf, 2005

Brachycarcharias mississippiensis (Case, 1994)

(Fig. 4.1 and 4.2)

Referred material: UALVP 55680, fractured anterior tooth; UALVP 55681, complete lower lateral tooth.

Description: The anterior tooth has a relatively broad and short median cusp that is flanked by a single pair of lateral cusplets. The apex of the mesial cusplet is missing in the only specimen. The smooth labial crown face is slightly convex and overhangs the labial root face significantly. The lingual crown face is strongly convex and bears some enameloid folding near the crown-root boundary. A narrow lingual neck is present.

Although the root is considerably damaged, the lingual protuberance appears to contain the upper portion of a nutrient groove. A deep basal concavity separates the slightly more elongated mesial root lobe from the distal lobe.

The lower lateral tooth also has a medial cusp with a lingually striated crown face and smooth labial face. Laterally positioned to a pair of well-developed lateral cusplets is 
a second pair of incipient cusplets. The basal concavity of the root is relatively shallow and separates a slightly more robust distal lobe from the mesial lobe.

Remarks: Brachycarcharias has been reported from Paleocene and Eocene deposits of Europe and Africa (Cappetta 2012). Although a portion of the lingual protuberance is missing in UALVP 55680, the extensive overhang and overall morphology of the median cusp closely resembles Brachycarcharias mississippiensis Case (1994, as Pseudodontaspis mississippiensis) from the late Paleocene and early Eocene of Mississippi. Cappetta (2006) considers B. mississppiensis to be synonymous with $B$. lerichei.

Family Mitsukurinidae Jordan, 1898

Genus Striatolamia Glickman, 1964

Striatolamia macrota (Agassiz, 1843)

(Figs. $4.3-4.6)$

Referred material: UALVP 55682, complete anterior tooth; UALVP 55683, slightly fractured lateral tooth; UALVP 55684, complete lateral tooth; UALVP 55685, slightly fractured anterior tooth.

Description: Anterior teeth have a tall median cusp that is slightly distally inclined and weakly sigmoidal in profile. A distinct cutting edge runs continuously across the cusp and a pair of significantly reduced (at times absent) lateral cusplets. The labial crown face is very slightly convex, whereas the lingual face is strongly convex and bears welldeveloped enameloid striations. A narrow lingual neck is present. The lingual protuberance contains a distinct nutrient groove that houses a large nutrient foramen. The 
somewhat divergent root lobes are separated by a deep basal concavity. The distal root lobe is clearly more elongated than the mesial lobe.

Lateral teeth have a median cusp with a strong distally inclination. The root lobes are more divergent than that of the lobes of anterior teeth. The distal lobe is also considerably more robust than the medial lobe.

Remarks: Based on reduced lateral cusplets, stronger lingual enameloid folding, and a profile view that is less sigmoidal, we follow Siverson (1995), Cappetta and Nolf (2005), and Cappetta (2012) in assigning this species to the family Mitsukurinidae rather than Odontaspididae.

Striatolamia macrota is a cosmopolitan species having been reported from Eocene deposits of Europe (Agassiz 1843; Leriche 1905, 1906; Kemp et al. 1990; Adnet 2006), central Asia (Zhelezko and Kozlov 1999; King et al. 2013), northern Africa (Arambourg 1952), Australia (Pledge 1967), South America (Otero and Soto-Acuña 2015), and Antarctica (Long 1992). In North America, reports include Virginia (Ward and Wiest 1990; Kent 1999a; Müller 1999), North Carolina (Case and Borodin 2000), Georgia (Parmley and Cicimurri 2003), Mississippi (Case 1994), and Texas (Westgate 1989). Recently, this species was recovered from an Arctic deposit on Banks Island, Northwest Territories, Canada (Padilla et al. 2014).

Genus Anomotodon Arambourg, 1952

Anomotodon sp.

(Fig. 4.7)

Referred material: UALVP 55686, slightly fractured lateral tooth. 
Description: The lateral tooth has a median cusp that is distally inclined. The distal cutting edge is shorter than the mesial edge and is coupled with an oblique shoulder that bears an incipient cusplet. There is no clear distinction between the mesial edge of the cusp and the mesial heel. The labial crown face is slightly convex and bears short enameloid folding just above the crown-root boundary. The lingual face is slightly more convex than the labial face but is completely smooth. A lingual neck is present. The root is low and contains a weak lingual protuberance housing a well-developed nutrient groove. The basal concavity is relatively shallow and separates more or less symmetrical root lobes.

Remarks: The fossil record of Anomotodon extends from the Early Cretaceous to the late Eocene and has been reported from Europe, northern and western Africa, Asia (Cappetta 2012), and Antarctica (Long 1992). Two species are known from the Paleogene of North America: A. cravenensis Case, 1980 from the Oligocene of North Carolina and A. novus (Winkler, 1876) from the late Paleocene and early Eocene of Virginia (Kent 1999a; Müller 1999). The latter species was originally described from the Lutetian of Belgium (Winkler 1876). Kent (1999a) noted that the heel morphology of teeth reported as Anomotodon sp. by Case (1994) from the late Paleocene and early Eocene of Mississippi differs from that of $A$. novus. UALVP 55686 has a similar morphology to the lateral teeth from the Mississippi assemblage (compare with Case 1994, pl. 7, figs., 141 and 147) and is likely conspecific.

Order Carcharhiniformes Compagno, 1973

Family Scyliorhinidae Gill, 1862 
Genus Premontreia Cappetta, 1992

Premontreia (Oxyscyllium) gilberti (Casier, 1946)

(Fig. 5.1)

Referred material: UALVP 55687, complete anterior tooth.

Description: The anterior tooth contains a tall median cusp that is flanked by a pair of well-developed and divergent lateral cusplets. A cutting edge runs continuously across the cusp and cusplets. The basal region of the labial crown face bears distinct enameloid folding, is slightly depressed medially, and very slightly overhangs the root. The lingual face is strongly convex and weak folding is apparently on the cusplets. The basal face of the root is greatly expanded and divided by a well-developed nutrient groove.

Remarks: Kent (1999a) reported Premontreia degremonti Cappetta, 1992, from the early Eocene of Virginia. UALVP 55687 has a more robust median cusp and larger and more divergent lateral cusplets, and morphologically resembles the teeth of Premontriea (Oxyscyllium) gilberti.

Premontriea (Oxyscyllium) gilberti has been reported from early and middle Eocene deposits of Europe (Casier 1946; Cappetta 1976; Bor 1985; Adnet 2006) and central Asia (Case et al. 1996). In North America, this species has been previously reported as Scyliorhinus gilberti from the Ypresian of Virginia (Kent 1999a), Georgia (Parmley and Cicimurri 2003), and Mississippi (Case 1994). Adnet (2006) reassigned $S$. gilberti to Premontreia, a view supported herein.

Family Triakidae Gray, 1851

Genus Pachygaleus Cappetta, 1992 
Pachygaleus lefevrei (Daimeries, 1891)

(Fig. 5.2 and 5.3)

Referred material: UALVP 55688, fractured lateral tooth; UALVP 55689, complete lateral tooth.

Description: The lateral tooth is mesiodistally elongated and labiolingually thick. The crown possesses a cusp that is strongly distally inclined. The mesial cutting edge is very slightly sigmoidal and smooth. The distal cutting edge is slightly convex and also smooth. The distal heel is oblique and bears five cusplets that decrease in size distally. The smooth labial crown face is convex and clearly overhangs the labial root face forming a concave basal edge. The lingual crown face is also smooth and convex. The basal face of the root is large, more or less flat, and contains a distinct nutrient groove and multiple foramina. The basal concavity is very shallow.

Remarks: Pachygaleus is monotypic and has been recovered from the Ypresian of Europe (Leriche 1905; Cappetta 1992; Adnet 2006). In North America, P. lefevrei has been reported from Virginia (Kent 1999a) and from Mississippi (Case 1994, as Galeorhinus lefevrei). Kent (1999a) questioned the identity of the teeth from Mississippi, given the low number of cusplets on the distal heel; however, this may be a pathologic feature as the overall morphology closely resembles that of $P$. lefevrei. Although the root of UALVP 55688 is heavily eroded, we refer this specimen to P. lefevrei. Adnet and Cappetta (2008) noted that the mesial cutting edge is most often smooth; however, serrations may occur, as observed in this specimen.

Family Carcharhinidae Jordan and Evermann, 1896 
Genus Abdounia Cappetta, 1980

Abdounia beaugei (Arambourg, 1935)

(Fig. 5.4 and 5.5)

Referred material: UALVP 55690, complete anterior tooth; UALVP 55691, complete anterolateral tooth.

Description: Teeth have a tall median cusp with a relatively sharp apex. The median cusp of anterior tooth is flanked by a single pair of divergent lateral cusplets, whereas the anterolateral tooth has two pairs of lateral cusplets. On both teeth, a cutting edge runs continuously across the cusp and cusplets. The labial crown face is more or less flat and smooth. The lingual face is convex and also smooth. The basal face of the root is expanded and divided by a well-developed nutrient groove housing a nutrient foramen. Remarks: Abdounia beaugei has been reported from the early and middle Eocene of Europe (Leriche 1936; Kemp et al. 1990), northern Africa (Arambourg 1935; Noubhani and Cappetta 1997), and central Asia (Case et al. 1996). Along with this species, $A$. lapierrei Cappetta and Nolf, 1981, A. recticona (Winkler, 1874), and A. minutissima (Winkler, 1874) has been from reported from early Eocene deposits of Virginia (Ward and Wiest 1990; Kent 1999a; Müller 1999). Case (1994) reported A. beaugei and A. subulidens (Arambourg, 1952) from the early Eocene of Mississippi. The latter was reassigned to $A$. aff. A. minutissima by Adnet (2006). The occurrence of only a single species of Abdounia at the Jamestown site is somewhat unexpected given that multiple species were recovered from the other North American deposits.

Genus Physogaleus Cappetta, 1980 
Physogaleus secundus (Agassiz, 1843)

(Fig. 5.6 and 5.7)

Referred material: UALVP 55692, complete lateral tooth; UALVP 55693, fractured anterolateral tooth.

Description: The lateral tooth is mesiodistally elongated and possesses a cusp that is strongly distally inclined. The mesial cutting edge is very slightly sigmoidal convex and bears a number of irregular serrations near the base. The distal cutting edge is convex and smooth and forms a distinct notch with the distal heel. The distal heel is oblique and bears irregular and very weak serrations. The smooth labial crown face is more or less flat, whereas the smooth lingual crown face is convex. The basal face of the root is expanded and divided by a well-developed nutrient groove housing a very large nutrient foramen. Numerous large foramina are also found labially below the crown-root boundary.

The cusp of the anterolateral tooth is narrower. The remainder of the tooth is heavily eroded.

Remarks: Physogaleus secundus has been reported from the early Eocene of Europe (Leriche 1905; Casier 1966), south and central Asia (Kumar et al., 2007; King et al. 2013), and northern Africa (Arambourg 1952; Noubhani and Cappetta 1997).

Multiple species of Physogaleus have been reported from the early Eocene of North America. Müller (1999) described the species P. latecuspidatus from Virginia, whereas Ward and Wiest (1990) and Kent (1999a) only reported P. secundus from this region. Along with describing the new species $P$. americanus, Case (1994) reported $P$. tertius and Physogaleus sp. from the early Eocene of Mississippi. Kent (1999a, p. 26) suggested that teeth of $P$. americanus were "size and gender variants of $P$. secundus"; 
however, it should be noted that Cappetta $(2006,2012)$ recognizes $P$. americanus as a valid species. Recently, Physogaleus secundus and teeth described as $P$. cf. $P$. americanus were reported from the early to middle Eocene of the Northwest Territories, Canada (Padilla et al. 2014).

Superorder Batomorphii Cappetta, 1980

Order Rajiformes Berg, 1940

Family Rhinobatidae Müller \& Henle, 1838

Genus Rhinobatos Linck, 1790

Rhinobatos sp.

(Fig. 6.1)

Referred material: UALVP 55694, complete tooth.

Description: The tooth is extremely small and non-cuspidate. A blunt transverse edge separates the smooth and slightly convex labial and lingual crown faces. The labial crown edge is rounded and convex. The lingual crown edge contains a well-developed median uvula that has a 'V-shaped' extremity. This structure is flanked by less-developed and diverging lateral uvulae. The root is positioned lingually below the crown and contains a nutrient groove that bears a large foramen. Additional margino-lingual foramina are present.

Remarks: Due to the conservative nature of rhinobatoid tooth morphology, it is likely that many fossil species attributed to Rhinobatos in fact belong to different taxa (Kriwet 1999; Kriwet et al. 2009; Cappetta 2012). We tentatively identify UALVP 55694 as Rhinobatos sp. and recognize that future reassignment is probable. 
Rhinobatos bruxelliensis (Jaekel, 1894), originally described from the middle Eocene of Belgium, has been reported from the early Eocene of North American including Maryland (Ward and Wiest 1990) and Virginia (Kent 1999b). The tooth morphology of UALVP 55694 differs from this species by having shorter lateral uvulae and a median uvula with a 'V-shaped', rather than rounded, extremity (see Jaekel 1894, p.77, fig. 8).

UALVP 55694 has an overall morphology very similar to that of teeth identified as Rhinobatos sp. from the late Paleocene and early Eocene of Mississippi (Case 1994) and is most likely conspecific.

Order Torpediniformes de Buen, 1926

Family Torpedinidae Bonaparte, 1838

Genus Eotorpedo White, 1934

Eotorpedo hilgendorfi (Jaekel, 1904)

(Fig. 6.2)

Referred material: UALVP 55695, complete lateral tooth.

Description: Lateral tooth with a tall, narrow, and lingually directed cusp that is slightly distally inclined. Both crown faces are strongly convex. A blunt cutting edge is restricted to the upper half of the cusp. The labial crown basal edge is strongly concave and is notched medially, producing two distinct and elongated margino-labial protuberances. The lingual crown edge bears a deep notch medially. The bilobate root is low and extends lingually beyond the crown margin. 
Remarks: This species was reported by Knight et al. (2007) from the same Jamestown, South Carolina site discussed herein. It was the first reported occurrence of this species from North America. Eotorpedo hilgendorfi has been reported from numerous early Paleocene through early Eocene deposits of northern and western Africa (Jaekel 1904; Dartevelle and Casier 1943; Arambourg 1952; Cappetta 1972, 1988).

\author{
Order Myliobatiformes Compagno, 1973 \\ Family Gymnuridae Fowler, 1934 \\ Genus Jacquhermania Cappetta, 1982 \\ Jacquhermania duponti (Winkler, 1874)
}

(Fig. 6.3 and 6.4)

Referred material: UALVP 55696, complete anterior tooth; UALVP 55697, complete lateral tooth.

Description: The anterior tooth has a tall, narrow, and lingually directed cusp. The labial crown face is slightly concave and smooth. The labial crown edge is strongly concave, producing two distinct margino-labial protuberances. A distinct cutting edge extends from the apex to the protuberances. The smooth lingual crown face is convex and has a slightly concave lingual edge. The bilobate root is positioned lingually below the crown and contains a well-developed nutrient groove.

The lateral tooth has a somewhat broader crown bearing a shorter cusp.

Remarks: This species has been reported from early and middle Eocene deposits of Europe (Winkler 1876; Cappetta 1982; Kemp et al. 1990; Adnet and Cappetta 2008) and Virginia (Kent 1999b). Cappetta (2012) reassigned the teeth identified as Eotorpedo 
jaekeli White, 1934 by Case (1994) from the early Eocene of Mississippi to J. duponti. UALVP 55694 and UALVP 55695 represent the first known report of $J$. duponti from South Carolina.

Family Myliobatidae Bonaparte, 1838

Genus Meridiania Case, 1994

Meridiania convexa Case, 1994

(Fig. 6.5 and 6.6)

Referred material: UALVP 55698, complete median tooth; UALVP 55699, complete lateral tooth.

Description: The median tooth is mesiodistally elongated, hexagonal, and has a welldeveloped convex occlusal surface. Both labial and lingual crown faces are smooth or very slightly irregular. A distinct lingual bulge is present. The polyaulacorhizous root bears numerous wide lobelets.

The lateral tooth also has a hexagonal crown but is mesiodistally shorter than that of the median tooth. The occlusal surface of the crown is dome-like. The labial face of the crown is slightly concave, whereas all other faces are slightly convex. A distinct lingual bulge is present. The bilobate root is positioned lingually below the crown and contains a well-developed nutrient groove.

Remarks: The original description of Meridiania convexa was based on lateral teeth recovered from the Bashi Formation of Meridian, Lauderdale County, Mississippi (Case 1994). Elongated median teeth were not recovered from the type locality and the species was assigned to Dasyatidae Jordan, 1888. Teeth of similar morphology were also 
reported from the early Eocene of Virginia (Kent 1999b) and eastern Texas (Cicimurri 2010).

Case et al. (2011) erected Eorhinoptera grabdai based on a limited number of mesiodistally elongated teeth, similar to UALVP 55698, recovered from the Jamestown quarry. On the basis of abundant material from the same quarry, Cicimurri (2010, p. 99) independently described the mesiodistally elongated specimens of similar morphology and suggested that the teeth were medially positioned dentition of a "closely packed (but not rigid) arrangement of teeth" belonging to Meridiania convexa. He noted that previous reports of $M$. convexa were based strictly on laterally positioned teeth within the jaw of the species as he reconstructed the dentition. He further stated that $M$. convexa should be reassigned to Myliobatidae, a notion supported by Cappetta (2012). Herein, we also support the dental reconstruction and taxonomic placement of Cicimurri (2010) and now consider E. grabdai to be synonymous with M. convexa.

Genus Myliobatis Cuvier, 1816

Myliobatis sp.

(Fig. 7.1)

Referred material: UALVP 55700, complete median tooth.

Description: The median tooth is mesiodistally elongated, hexagonal, and slightly arched. The occlusal face of the crown is smooth and flat. The labial face is more or less smooth, whereas the lingual faces bear very weak enameloid ridges and have a distinct lingual bulge. The polyaulacorhizous root is low and lingually positioned. 
Remarks: From early Eocene deposits of eastern North America, Kent (1999b) reported Myliobatis dixoni (Agassiz, 1843), M. latidens (Woodward, 1888), and M. striatus (Buckland, 1837) from Virginia. In that document, the taxa were largely differentiated based on differences in tooth dimensions. Ward and Wiest (1990) also reported M. dixoni from that region but left additional species in open nomenclature.

In their discussion of selachian assemblages from the Eocene of Egypt, Underwood et al. (2011, p. 59) noted that Myliobatis requires "considerable taxonomic work". Cappetta (2012) also suggested that a revision of Myliobatis will most certainly reduce the number of species placed within this taxon. Due to the limited number of specimens recovered from the Jamestown site, we conservatively leave this species in open nomenclature but note that UALVP 55700 shares an overall morphology similar to teeth reported as M. dixoni from the early Eocene of Mississippi (Case 1994).

Family Mobulidae Gill, 1893

Genus Burnhamia Cappetta, 1976

Burnhamia aff. B. daviesi (Woodward, 1889)

(Fig. 7.2)

Referred material: UALVP 55701, complete median tooth.

Description: The median tooth is mesiodistally elongated and hexagonal in shape. The occlusal face of the crown is smooth and concave. The labial and lingual faces are of similar height in profile view. Both crown faces have irregular edges. A distinct lingual bulge is present. The polyaulacorhizous root is lingually positioned and possesses tall and narrow lobelets. 
Remarks: Burnhamia daviesi has been reported from numerous late Paleocene through late Eocene deposits including Europe (e.g., Woodward 1889; Leriche 1905, 1906; Casier 1946; 1966; Cappetta 1976; Bor 1985; Adnet 2006), and central Asia (e.g., Averianov and Udovichenko 1993; Case et al. 1996). North American occurrences include Virginia (Ward and Wiest 1990; Kent 1999b) and Mississippi (Case 1994). The morphology of UALVP 55701 somewhat differs from that of $B$. daviesi by the relatively similar height of the labial and lingual crown face (compare profile view with Cappetta 2012, fig. $453 \mathrm{~K})$. As well, the latter face is strongly concave and bears highly irregular enameloid. Consequently, we conservatively report this specimen as Burnhamia aff. B. daviesi.

Myliobatiformes, incertae fam.

Genus Hypolophodon Cappetta, 1980

Hypolophodon dockeryi (Case, 1994)

(Fig. 7.3)

Referred material: UALVP 55702, complete tooth.

Description: The tooth is slightly mesiodistally elongated and has a crown that is more or less hexagonal in shape. The occlusal surface of the crown is wider than the basal region of the crown. The lingual marginal face is very slightly concave, whereas all other faces are very slightly convex. A weakly developed lingual uvula is present. All faces are smooth. The bilobate root is shorter than the crown and is offset lingually. The root is divided by a well-developed nutrient groove containing several nutrient foramina. There are also numerous foramina found just below the crown-root boundary. 
Remarks: Hypolophodon dockeryi was originally described by Case (1994, as Platyrhina dockeryi) from the early Eocene of Mississippi. Ward and Wiest (1990) and Kent (1999b) reported H. sylvestris (White, 1931) from the late Palaeocene and early Eocene of Maryland and Virginia. The latter species can be differentiated from $H$. dockeryi by the presence of enameloid folding on the basal region of the lingual face of the crown. It should be noted, however, that Kent (1999b) indicated the absence of this character in juvenile H. sylvestris. Given the rather diminutive size of UALVP 55702, it is possible that this tooth could in fact belong to a juvenile of the latter species.

Case (1994) noted the similarity in tooth morphology between $H$. dockeryi and Pseudohypolophus Cappetta and Case, 1975; however, histological differences in dentine and the presence of a distinct lingual uvula in the former distinguish these species (Cappetta 2012). UALVP 55702 represents only the second documented report of $H$. dockeryi.

Genus Coupatezia Cappetta, 1982

\section{Coupatezia sp.}

Referred material: UALVP 55703, complete tooth.

Description: The tooth is small and its crown is elliptical. Both the labial and lingual edges of the crown are slightly concave medially. A distinct transverse crest is present. The convex labial face of the crown has a finely ornamented enameloid surface and a very weak labial transverse ridge. The flat lingual face is shorter and more steeply inclined than the labial face in profile view. The root is lingually directed and extends 
beyond the lingual crown edge. A nutrient groove is present and bears a large nutrient foramen.

Remarks: Coupatezia woutersi has been reported from late Paleocene and Eocene deposits of Europe (Leriche 1905, 1906; Cappetta 1982; Adnet 2006), central Asia (Case et al. 1996), and northern Africa (Murray et al. 2010). In North America, this species has been reported from Maryland (Ward and Wiest 1990), Virginia (Kent 1999b), and Mississippi (Case 1994). The tooth morphology of UALVP 55702 differs from that of $C$. woutersi by having a very weak labial transverse ridge.

The crown morphology of UALVP 55703 somewhat resembles that of Coupatezia boujoi Noubhani and Cappetta, 1997, from the Ypresian of Morocco. Both have a depressed labial face with a weak labial transverse ridge and ornamentation that is very fine and diffuse. However, based on the limited number of specimens collected, we conservatively leave this species in open nomenclature.

\section{Discussion}

The Jamestown assemblage described herein includes 22 species belonging to eight orders, at least 15 families, and 21 genera and includes the first report of Protoginglymostoma from North America.

\section{Palaeoecology}

Many of the recovered species from the Jamestown site have dentition consistent with that of young and/or small individuals. As discussed above, the anterior tooth of Heterodontus cf. sowasheense has well-developed and divergent lateral cusplets. These 
characters are known ontogenetic variants found in juveniles from this genus (Reif 1976; Cappetta 2012). There is also a paucity of sizeable dentition from several of the larger species in this assemblage. For example, Cappetta (2012) noted that the anterior teeth of Striatolamia can exceed $5 \mathrm{~cm}$ in height. Kent (1999a, pl.2.2B) reported a height of $4.3 \mathrm{~cm}$ for a $S$. macrota anterior tooth recovered from the Ypresian of Virginia. The largest anterior tooth from the Jamestown assemblage is little more than $1 \mathrm{~cm}$ in height, suggesting it likely belonged to a young shark. The recovered Anomotodon lateral tooth is also likely from a smaller individual, as it is less than $5 \mathrm{~mm}$ in height. Accordingly, it is plausible that the Jamestown site may represent a nursery ground and/or refuge for young and smaller individuals. Edwards et al. (2000) noted the presence of ostracodes from the Fishburne Formation that suggest deposition in warm shallow water and would accommodate such a habitat. Nursery areas are utilized by many extant species (Springer 1967) as they provide both abundant nutrients and protection from predation. The apparent absence of relatively large macrophagous species (e.g., Cretalamna Glickman, 1958) found in other contemporaneous assemblages along the Atlantic and Gulf coastal plains (see Case 1994; Kent 1999a), further supports this notion.

\section{Palaeobiogeography}

A faunal comparison between the Jamestown assemblage and other early and middle Eocene assemblages provides important insight into selachian palaeobiogeography (Table 1). Of the species reported herein, Striatolamia macrota had the most extensive palaeodistribution, having been reported from deposits on multiple continents (see Cappetta 2012). This circumglobal range is somewhat similar to that of 
the only extant mitsukurinid, Mitsukurina owstoni Jordan, 1898. However, the latter species differs by inhabiting the deeper waters of outer continental shelves and slopes (Compagno 2001; Musick et al. 2004; Nelson 2006). It should be noted that several Paleogene species of Anomotodon, such as A. sheppeyensis (Casier, 1966), A. novus, and A. cravenensis, had a more limited range (see Cappetta 2012).

Other species had relatively large palaeobiogeographical ranges within the Northern Hemisphere. The palaeodistribution of Abdounia beaugei and Physogaleus secundus is comparable to that of numerous extant carcharhinids with high vagility (Musick et al. 2004). Of the two ginglymostomatid species recovered from the Jamestown site, Protoginglymostoma ypresiensis appears to have had a more extensive palaeodistribution that included both Tethyan (e.g., Tabuce et al. 2005) and Atlantic (i.e., Casier 1946; this report) waters. Conversely, Nebrius thielensis appears to have been restricted to the North Atlantic. The large palebiogeographical range of Palaeorhincodon is to be expected, as only extant rhincodontid, Rhincodon typus Smith, 1828, is circumtropical (Musick et al. 2004). Several extant triakids, e.g., Galeorhinus galeus (Linnaeus, 1758), Mustelus mustelus (Linnaeus, 1758), and Hemipritis elongates Klunzinger, 1871, have relatively large biogeographical ranges (Compagno et al. 2005); thus the report of Pachygaleus lefevrei from both North American (e.g., Kent 1999a; this report) and European (e.g., Adent 2006) deposits is not surprising. On the other hand, the occurrence of the Premontreia (Oxyscyllium) gilberti in deposits from either side of the Atlantic is somewhat curious, as most extant scyliorhinids are benethic and have rather small biogeographical ranges (Compagno et al. 2005). However, Musick et al. (2004, p. 
49) noted that "moderate vagility and may have served as a vehicle for the circumglobal distribution of some genera" within the family.

The extensive palaeobiogeographical range of Squatina prima is questionable. Extant Squatina have limited vagility (Musick et al. 2004), and reports of this species from multiple continents may be due to the conservative nature of the dentition of Squatina (Cappetta 2012).

A number of the species recovered in the Jamestown assemblage may have been restricted to western Atlantic waters. The lack of reported occurrences of Brachycarcharias mississippiensis outside North America is curious, as extant odontaspidids have a rather high vagility and a circumglobal distribution (Musick et al. 2004). The congeneric species $B$. lerichei has been reported from the early Eocene of Europe (e.g., Casier 1946; Cappetta and Nolf 2005) and North America (e.g., Kent 1999a, as Serratolamna lerichei).

The fossil record of Heterodontus extends back to the Middle Jurassic (Musick et al. 2004; Cappetta 2012). Extant species have limited biogeographical ranges and inhabit the shallow continental and insular waters of the western and eastern Pacific and Indian Oceans, but are absent in Atlantic waters (Compagno 2001; Nelson 2006). Musick et al. (2004) suggested that this rather curious present-day distribution could stem from the vicariant breakup of Pangaea, when Heterodontus tracked from the eastern margin of the supercontinent to the emerging eastern, then western Atlantic Ocean, and finally to the eastern Pacific Ocean before the formation of Panamanian Isthmus. The recovery of numerous Late Cretaceous and Paleogene species from deposits on both sides of the Atlantic supports this notion. The report of $H$. lerichei from both the late Thanetian of 
Belgium (Casier 1943) and the early Eocene of Virginia (Ward and Wiest 1990; Kent 1999a) is somewhat suspect, given that extant species have low vagility. Conversely, the rather restricted range of $H$. cf. $H$. sowasheense is to be expected.

Musick et al. (2004, p. 45) also noted that the occurrence of the genus Hemiscyllium in the upper Paleocene and lower Eocene of Belgium is "enigmatic" given Australian endemism and low vagility of its present-day species. However, additional species have been reported from multiple Campanian to Eocene deposits of Europe (see Kriwet et al. 2007) and northern Africa (Noubhani and Cappetta 1997). Close proximity to Europe during the Cretaceous may explain the occurrence of Hemiscyllium from the Campanian of Mississippi (Case 1991), Maastrichtian of New Jersey (Case 1995), and subsequently the early Eocene of South Carolina (this report). Although the teeth recovered from the Jamestown site bear close resemblance to those of Hemiscyllium bruxelliensis from the Lutetian of Belgium (Herman 1977b), it is unlikely that they are conspecific given the large geographical separation.

Of the batomorphs recovered from the Jamestown site, the mobulid Burnhamia daviesi had the most extensive palebiogeographical range, which included both North Atlantic (e.g., Cappetta 1976, Adnet 2006, Kent 1999b) and northern Tethyan deposits (e.g., Averianov and Udovichenko 1993; Case et al. 1996). Conversely, Eotorpedo hilgendorfi may have been restricted to relatively warmer waters in view of the fact that it has only been reported from northern and western Africa (Jaekel 1904; Dartevelle and Casier 1943; Arambourg 1952; Cappetta 1972, 1988) and South Carolina (Knight et al. 2007; this report). Ebert and Stehmann (2013) noted that most extant torpedinids are generally inactive, but a few species are highly migratory. This may account for the 
occurrence of E. hilgendorfi in deposits on both sides of the Atlantic. The biogeographical range of the extant gymnurid, Gymnura altavela (Linnaeus, 1758) is extensive; it inhabits swallow inshore waters on both sides of the North and South Atlantic. Thus, the report of Jacquhermania duponti from both European (e.g., Cappetta 1982; Kemp et al. 1990; Adnet and Cappetta 2008) and North America (e.g., Kent 1999b; this report) is not unexpected. Although the familial status of Coupatezia is uncertain, Cappetta (2012) recognizes this taxon as a dasyatoid. As discussed previously, the teeth of Coupatezia sp. from the Jamestown site morphologically resemble those of Coupatezia boujoi from the Ypresian of Morocco (Noubhani and Cappetta 1997). The extant dasyatids, Pteroplatytrygon violacea (Bonaparte, 1832) and Dasyatis centroura (Mitchill, 1815) have an extensive biogeographical range that includes shallow inshore waters of the eastern and western Atlantic (Ebert and Stehmann 2013); thus, it is not inconceivable that the Jamestown material is conspecific with the North African species. The limited biogeographical range for Meridiania convexa and Hypolophodon dockeryi is not surprising and is consistent with the small biogeographical range of numerous extant benthic myliobatiforms. Finally, despite the taxonomy uncertain of many species of Rhinobatos and Myliobatis caused by the conservative nature of their dentition, many extant North Atlantic species, such as Rhinobatos (Rhinobatos) rhinobatos (Linnaeus, 1758) and Myliobatis aquila (Linnaeus, 1758), have rather large distributions (Ebert and Stehmann 2013). Therefore, the extensive palaeodistribution reported for Rhinobatos bruxelliensis and Myliobatis dixoni is plausible.

\section{Acknowledgements}


The authors are very appreciative of David W. Grabda (Myrtle Beach, South Carolina) and Paul D. Borodin (Little River, South Carolina) for the many hours they invested in collecting the specimens described herein. The authors also extend their gratitude to the staff at the Scanning Electron Microscope Laboratory (Department of Earth and Atmospheric Sciences, University of Alberta) and Jerry Magraw (Penn State Erie, The Behrend College) for assistance with imaging and to M. Templin for French translation of key references. Comments by C. Underwood (Birkbeck, University of London), Jürgen Kriwet (University of Vienna), an anonymus reviewer, and Ali Polat (editor) greatly improved the manuscript. The research of MVHW on this project was supported by NSERC Discovery Grant A9180 to MVHW.

\section{References}

Adnet, S. 2006. Nouvelles faunes de sélaciens (Elasmobranchii, Neoselachii) de l'Éocène des Landes (Sud-Ouest, France). Implication dans les connaissances des communautés d'eaux profondes. Palaeo Ichthyologica, 10: 1-128.

Adnet, S., and Cappetta, H. 2008. New fossil triakid sharks from the Eocene of Prémontré, France, and comments on fossil record of the family. Acta Palaeontologica Polonica, 53: 433-448.

Agassiz, J.L.R. 1833-1844. Recherches sur les poissons fossils, 3. Imprimerie de Petitpierre, Neuchâtel.

Allen, G.R., Erdmann, M.V., Dudgeon, C.L. 2013. Hemiscyllium halmahera, a new species of Bamboo Shark (Hemiscylliidae) from Indonesia. Aqua, International Journal of Ichthyology 19: 123-136. 
Arambourg, C. 1935. Note préliminaire sur les vertébrés fossiles des phosphates du Maroc. Bulletin de la Société Géologique de France, 5: 413-439.

Arambourg, C. 1952. Les vertébrés fossiles des gisements de phosphates (Maroc, Algérie, Tunisie). Notes et Mémoires du Service Géologique, Maroc, 92: 13-72.

Averianov, A.O. and Udovichenko, N.I. 1993. Age of vertebrates from the Andarak locality (southern Fergana). Stratigraphy and Geological Correlation, 1: 139141.

Berg, L.S. 1937. A classification of fish-like vertebrates. Bulletin de l'Académie des Sciences de l'URSS. Classe des Sciences Mathématiques et Naturelles, 1937: $1277-1280$.

Berg, L.S. 1940. Classification of fishes both recent and fossil. Trudy Zoologiceskogo Instituta, Akademia Nauk S.S.S.R., Leningrad, 5: 87-517.

Berg, L.S. 1958. System der rezenten und fossilen Fischartigen und Fische. Hochschulbücher für Biologie, Berlin, pp. 1-310.

Blainville, H.M.D., de. 1816. Prodrome d'une nouvelle distribution systématique du règne animal. Bulletin des Sciences, par la Société Philomatique de Paris, 8: $105-124$.

Bonaparte, C.L. 1832. Iconografia della fauna italica per le quattro classi degli animali vertebrati. Tomo III. Pesci. Roma.

Bonaparte, C.L. 1838. Selachorum tabula analytica. Nuovi Annali della Scienze Naturali, Bologna, 1: 195-214. 
Bor, T.J. 1985. Elasmobranch teeth (Vertebrata, Pisces) from the Dongen Formation (Eocene) in the Netherlands. Mededelingen Van De Werkgroep Voor Tertiaire En Kwartaire Geologie, 22: 73-122.

Buckland, W. 1837. Geology and mineralogy considered with reference to natural theology. Carey, Lea, and Blachard, Philadelphia, pp. 1-131.

Cappetta, H. 1972. Les poissons Crétacés et Tertiaires du bassin des Iullemmeden (République du Niger). Palaeovertebrata, 5: 179-251.

Cappetta, H. 1976. Sélaciens nouveaux du London Clay de l'Essex (Yprésien du Bassin de Londres). Géobios, 9: 551-575.

Cappetta, H. 1980. Modification du statut générique de quelques espèces de sélaciens Crétacés et Tertiaires. Palaeovertebrata, 10: 29-42.

Cappetta, H. 1982. Révision de Cestracion duponti WINKLER, 1874 (Selachii, Batomorphii) du Bruxellien de Woluwe-Saint-Lambert (Eocène moyen de Belgique). Mededelingen Van De Werkgroep Voor Tertiaire En Kwartaire Geologie, 19: 113-125.

Cappetta, H. 1988. Les Torpédiniformes (Neoselachii, Batomorphii) des phosphates du Maroc. Observations sur la denture des genres actuels. Tertiary Research, 10: $21-52$.

Cappetta, H. 1992. Carcharhiniformes nouveaux (Chondrichthyes, Neoselachii) de 1'Yprésien du Bassin de Paris. Geobios, 25: 639-646.

Cappetta, H. 2006. Elasmobranchii post-Triadici (index generum et specierum). In Fossilium Catalogus I: Aminalia 142. Edited by W. Riegraf. Backhuys Publishers, Leiden. 
Cappetta, H. 2012. Chondrichthyes. Mesozoic and Cenozoic Elasmobranchii: Teeth. In Handbook of Palaeoichthyology, Volume 3E. Edited by H.-P.Schultze. Verlag Dr. Friedrich Pfeil, München.

Cappetta, H., and Case, G.R. 1975. Sélaciens nouveaux du Crétacé du Texas. Géobios, 8: $303-307$.

Cappetta, H., and Nolf, D. 1981. Les sélaciens de l'Auversien de Ronquerolles (Eocène supérieur du Bassin de Paris). Mededelingen Van De Werkgroep Voor Tertiaire En Kwartaire Geologie, 18: 87-107.

Cappetta, H., and Tranverse, M. 1988. Une riche faune de sélaciens dans le bassin à phosphate de Kpogamé-Hahotoé (Éocène moyen du Togo): Note préliminaire et précisions sur la structure et l'âge du gisement. Géobios, 21: 359-365.

Cappetta, H., and Nolf, D. 2005. Révision de quelques Odontaspididae (Neoselachii: Lamniformes) du Paléocène et de l'Eocène du Bassin de la Mer du Nord. Bulletin de l'Institut Royal des Sciences Naturelles de Belgique, Science de la Terre, 75: 237-266.

Case, G.R. 1980. A selachian fauna from the Trent Formation, Lower Miocene (Aquitanian) of Eastern North Carolina. Palaeontographica, Abt. A, 171: 75103.

Case, G.R. 1981. Late Eocene selachians from South-central Georgia. Palaeontographica, Abt. A, 176: 52-79.

Case, G.R. 1987. A new selachian fauna from the Late Campanian of Wyoming (Teapot Sandstone Member, Mesaverde Formation, Big Horn Basin). Palaeontographica, Abt. A, 197: 1-37. 
Case, G.R. 1991. Selachians (sharks) from the Tupelo Tongue of the Coffee Sands (Campanian, Upper Cretaceous) in northern Lee County, Mississippi. Mississippi Geology, 11: 1-8.

Case, G.R. 1994. Fossil fish remains from the Late Paleocene Tuscahoma and Early Eocene Bashi Formations of Meridian, Lauderdale County, Mississippi. Part 1, Selachians. Palaeontographica A, 230: 97-138.

Case, G.R. 1995. Fossil shark remains from the early and middle Maastrichtian of the Upper Cretaceous of Monmouth County, New Jersey. In Contributions to the Paleontology of New Jersey. Edited by J. Baker. Geological Association of New Jersey, 12. pp. 72-80.

Case, G.R., and Borodin, P.D. 2000. A middle Eocene Selachian Fauna from the Castle Hayne Limestone Formation of Duplin County, North Carolina. Münchner Geowissenschaftliche Abhandlungen, (A), 39: 17-32.

Case, G.R., Cook, T.D., and Wilson, M.V.H. 2011. A new genus and species of fossil myliobatoid ray from the Fishburne Formation (lower Eocene/Ypresian) of Berkeley County, South Carolina, USA. Historical Biology, 23: 139-144.

Case, G.R., Udovichenko, N.I., Nessov, L.A., Averianov, A.O., and Borodin, P.D. 1996. A Middle Eocene Selachian Fauna from the White Mountain Formation of the Kizylkum Desert, Uzbekistan, C.I.S. Palaeontographica, Abt. A, 242: 99-126.

Casier, E. 1943. Contributions à l'étude des poissons fossiles de la Belgique. III. Quelques espèces nouvelles ou peu connues du Landénien marin. Bulletin du Musée Royal d'Histoire Naturelle de Belgique, 19: 1-16. 
Casier, E. 1946. La faune ichthyologique de l'Yprésien de la Belgique. Mémoires du Musée Royal d'Histoire Naturelle de Belgique, 104: 1-267.

Casier, E. 1966. Faune ichthyologique du London Clay. Trustees of the British Museum. pp. $1-496$.

Casier, E. 1966. Sur la faune ichthyologique de la Formation de Bissex Hill et de la Série océanique, de l'Ile de la Barbade, et sur l'âge de ces formations. Eclogae Geologicae Helvetiae, 59: 493-516.

Cicimurri, D.J., 2010. On the dentition of Meridiania convexa Case (Myliobatoidea), an extinct early Eocene ray from the United States. Cainozoic Research, 7: 1-2.

Cicimurri, D.J., and Knight, J.L. 2009. New record of an extinct fish, Fisherichthys folmeri Weems (Osteichthyes) from the lower Eocene of Berkeley County, South Carolina, USA. PaleoBios, 29: 24-28.

Compagno, L.J.V. 1973. Interrelationships of living elasmobranchs. In Interrelationships of Fishes. Edited by P.H. Greenwood, R.S. Miles, and C. Patterson. Zoological Journal of the Linnean Society, 53 (Supplement): 15-61.

Compagno, L.J.V. 1977. Phyletic relationships of living sharks and rays. American Zoologist, 17: 303-322.

Compagno, L.J.V. 2001. Sharks of the world. An annotated and illustrated catalogue of shark species known to date. Volume 2. Bullhead, mackerel and carpet sharks (Heterodontiformes, Lamniformes and Orectolobiformes). FAO Species Catalogue for Fishery Purposes. No. 1, Vol. 2. Rome.

Compagno, L.J.V., Dando, M., and Fowler, S. 2005. A Field guide to the Sharks of the World. HarperCollins Publishers Ltd., London. 
Cuvier, G. 1816. Le Règne Animal distribué d'après son organisation pour servir de base à l'histoire naturelle des animaux et d'introduction à l'anatomie comparée. Les reptiles, les poissons, les mollusques et les annélides. Deterville, Paris, pp. 1532.

Daimeries, A. 1891. Notes ichthyologiques - VI. Annales de la Société Royale Malacologique de Belgique, Bulletin des Séances, 26: 73-77.

Dartevelle, E., and Casier, E. 1943. Les poissons fossiles du Bas-Congo et des régions voisines. Annales du Musée du Congo Belge, Sér. A (Minéralogie, Géologie, Paléontologie), 3, 2: 1-200.

de Buen, F. 1926. Catalogo ictiologico del Mediterraneo Español y de Marruecos, recopilando lo publicado sobrepeces de las costas mediterraneas y proximas del Atlantico (Mar de España). Resultados de las ampafias Realizadas por Acuerdos Internacionales. Instituto Español de Oceanografia, 2: 1-221.

Duméril, A. 1806. Zoologie Analytique, ou Méthode Naturelle de Classification des Animaux. Allais, Paris.

Ebert, D.A., and Stehmann, M.F.W. 2013. Sharks, batoids, and chimaeras of the North Atlantic. FAO Species Catalogue for Fishery Purposes. No. 7. Rome, FAO.

Edwards, L.E., Gohn, G.S., Bybell, L.M., Chirico, P.G., Christopher, R.A., Frederiksen, N.O., Prowell, D.C., Self-Trail, J.M., and Weems, R.E. 2000. Supplement to the preliminary stratigraphic database for subsurface sediments of Dorchester County, South Carolina. United States Geological Survey Open-File Report, 00049-B: $1-44$. 
Fowler, H.W. 1934. Descriptions of new fishes obtained 1907 to 1910 , chiefly in the Philippine Islands and adjacent seas. Proceedings of the Academy of Natural Sciences of Philadelphia, 85: 233-367.

Garman, S. 1913. The Plagiostomia (Sharks, Skates and Rays). Memoirs of the Museum of Comparative Zoology at Harvard College, 36. pp. 1-528.

Gill, T.N. 1862. Analytical synopsis of the Order of Squali and revision of the nomenclature of the genera. Annals of the Lyceum of Natural History of New York, 7: 367-408

Gill, T.N. 1893. Families and subfamilies of fishes. Memoirs of the National Academy of Sciences, 6: 125-138.

Glickman, L.S. 1958. Rates of evolution in Lamnoid sharks. Dokl. Akad. Nauk SSSR, 123: 568-571. [In Russian]

Glickman, L.S. 1964. Sharks of Paleogene and their stratigraphic significance. Nauka Press, Moscow, pp. 1-229.

Gohn, G.S., Hazel, J.E., Bybell, L.M., and Edwards, L.E. 1983. The Fishburne Formation (lower Eocene), a newly defined subsurface unit in the South Carolina Coastal Plain. U.S. Geological Survey Bulletin, 1537-C: 1-16.

Gray, J.E. 1851. List of the Specimens of Fish in the Collection of the British Museum. Part I. Chondropterygii. British Museum (Natural History), London. pp. 1-160. Hay, O.P. 1902. Bibliography and catalogue of the fossil Vertebrata in North America. United States Geological Survey Bulletin, 179: 1-868. 
Herman, J. 1974. Compléments paléoichthyologiques à la faune éocène de la Belgique. 1. Palaeorhincodon, genre nouveau de l'Éocène belge. Bulletin de la Société Belge de Géologié, 83: 7-13.

Herman, J. 1977a. Les Sélaciens des terrains néocrétacés et paléocènes de Belgique et des contrées limitrophes. Eléments d'une biostratigraphie intercontinentale. Mémoires pour servir à l'explication des Cartes géologiques et minières de la Belgique, 15: 1-401.

Herman, J. 1977b. Additions to the Eocene fish fauna of Belgium. 3. Revision of the Orectolobiforms. Tertiary Research, 1: 127-138.

Herman, J. 1982. Die Selachier-Zähne aus der Maastricht-Stufe von Hemmoor, Niederelbe (NW-Deutschland). Geologisches Jahrbuch, Reihe A, 61: 129-159.

Huxley, T.H. 1880. On the application of the laws of evolution to the arrangement of the Vertebrata and more particularly of the Mammalia. Proceedings of the Zoological Society of London, 1880: 649-662.

Jaekel, O. 1894. Die eocänen Selachier vom Monte Bolca, pp. 1-176.

Jaekel, O. 1904. Ueber einen Torpediniden und andere Fischreste aus dem Tertiär von Kamerun. Beiträge zur Geologie von Kamerun, 4: 289-291.

Jordan, D. S. 1888. A Manual of Vertebrate Animals of the Northern United States, Including the District North and East of the Ozark Mountains, South of the Laurentian Hills, North of Virginia, and East of the Missouri River, Inclusive of Marine Species, Fifth Edition. Chicago. 
Jordan, D.S. 1898. Description of a species of fish (Mitsukurina owstoni) from Japan, the type of a distinct family of lamnoid sharks. Proceedings of the California Academy of Sciences, (Series 3, Zoology), 1: 199-202.

Jordan D.S., and Evermann B.W. 1896. The fishes of North and Middle America, a description catalogue of the species of fish-like vertebrates found in the waters of North America, north of the Isthmus of Panama. Part. 1. Bulletin of the United States National Museum, 47: 1-1240.

Kemp, D.J., Kemp, L., and Ward, D.J. 1990. An Illustrated Guide to the British Middle Eocene Vertebrates. Privately published, London.

Kent, B.W. 1999a. Sharks from the Fisher/Sullivan Site. In Early Eocene Vertebrates and Plants from the Fisher/Sullivan Site (Nanjemoy Formation) Stafford County, Virginia. Edited by R.E. Weems and G.J. Grimsley. Virginia Division of Mineral Resources Publication, 152: 11-37.

Kent, B.W. 1999b. Rays from the Fisher/Sullivan Site. In Fossil Vertebrates and Plants from the Fisher/Sullivan Site (Stafford County): A Record of Early Eocene Life in Virginia. Edited by R.E. Weems and G.J. Grimsley. Virginia Division of Mineral Resources, 152: 39-51.

King, C., Iakovleva, A., Steurbaut, E., Heilmann-Clausen, C., and Ward, D. 2013. The Aktulagay section, west Kazakhstan: a key site fornorthern mid-latitude Early Eocene stratigraphy. Stratigraphy, 10: 171-209.

Klunzinger, C.B. 1871. Synopsis der Fische des Rothen Meeres II. Theil. Verhandlungen der Königlischen Zoologischen-Botanischen Gesellschaft in Wien, 21: 441-688. 
Knight, J.L., Cicimurri, D.J., and Purdy, R.W. 2007. New Western Hemisphere occurrences of Schizorhiza Weiler, 1930 and Eotorpedo White, 1934 (Chondrichthyes, Batomorphii). Paludicola, 6: 87-93.

Kriwet J. 1999. Neoselachier (Pisces, Elasmobranchii) aus der Unterkreide (unteres Barremium) von Galve und Alciane (Spainien, Provinz Teruel). Palaeo Icthyologica, 9: 113-143.

Kriwet, J., Soler-Gijón, R., and López-Martínez, N. 2007. Neoselachians from the upper Campanian and lower Maastrichtian (Upper Cretaceous) of the southern Pyrenees, northern Spain. Palaeontology, 50: 1051-1071

Kriwet, J., Nunn, E.V., and Klug, S. 2009. Neoselachians (Chondrichthyes, Elasmobranchii) from the Lower and lower Upper Cretaceous of north-eastern Spain. Zoological Journal of the Linnean Society, 155: 316-347.

Kumar, K., Rana, R.S., and Singh, H. 2007. Fishes of the Khuiala Formation (Early Eocene) of the Jaisalmer Basin, Western Rajasthan, India. Current Science, 93: $553-559$.

Leidy, J. 1877. Description of vertebrate remains, chiefly from the Phosphate Beds of South Carolina. Journal of the Academy of Natural Sciences of Philadelphia, 8: 209-261.

Linnaeus, C. 1758. Systema Naturae per regna tria naturae, regnum animale, secundum classes, ordines, genera, species, cum characteribus differentiis synonymis, locis. Ed. X., Stockholm.

Leriche, M. 1905. Les poissons Éocènes de la Belgique. Mémoires du Musée Royal d'Histoire Naturelle de Belgique, 3: 49-228. 
Leriche, M. 1906. Contribution à lètude des poisons fossils du Nord de la France et des régions voisines. Mémoires de la Société Géologique du Nord, 5. pp. 1-430.

Leriche, M. 1936. Sur l'importance des squales fossiles dans l'établissement des synchronismes de formations à grandes distances et sur la répartition stratigraphique et géographique de quelques espèces Tertiares. Mémoires du Musée Royal d'Histoire Naturelle de Belgique, 3: 739-773.

Linck, H.F. 1790. Versuch einer Eintheilung der Fische nach den Zähnen. Magazin für das Neueste aus der Physik und Naturgeschichte, 6: 28-38.

Long, D.J. 1992. Sharks from the La Meseta Formation (Eocene), Seymour Island, Antarctica Peninsula. Journal of Vertebrate Paleontology, 12: 11-32.

Mitchill, S.L. 1815. The fishes of New York described and arranged. Transactions of the Literary and Philosophical Society of New York, 1: 355-492.

Müller, A. 1989. Selachier (Pisces: Neoselachii) aus dem höheren Campanium (Oberkreide) Westfalens (Nordrhein-Westfalen, NW-Deutschland). Geologie und Paläontologie in Westfalen, 14: 1-161.

Müller, A. 1999. Ichthyofaunen aus dem atlantischen Tertiär der USA. Leipziger Geowissenschaften, 9-10: pp. 1-360.

Müller, A., and Diedrich, C.G. 1991. Selachier (Pisces, Chondrichthyes) aus dem Cenomanium von Ascheloh am Teutoburger Wald (Nordrhein-Westfalen, NWDeutschland). Geologie und Paläontologie in Westfalen, 20: 3-105.

Müller, J., and Henle, F.G.J. 1838. On the generic characters of cartilaginous fishes, with descriptions of new genera. Magazine of Natural History and Journal of Zoology, Botany, Mineralogy, Geology and Meteorology, 2: 33-37; 88-91. 
Müller, J., and Henle, F.G.J. 1839-1841. Systematische Beschreibung der Plagiostomen. Berlin, unpaginated.

Murray, A.M., Cook, T.D., Attia, Y.S., Chatrath, P., and Simons, E.L. 2010. A freshwater ichthyofauna from the late Eocene Birket Qarun Formation, Fayum, Egypt. Journal of Vertebrate Paleontology, 30: 665-680.

Musick, J.A., Harbin, M.M., and Compagno, L.J.V. 2004. Historical zoogeography of the Selachii. In Biology of Sharks and Their Relatives. Edited by J.C. Carrier, J.A. Musick, and M.R. Heithaus. CRC Press, Boca Raton, pp. 33-78.

Nelson, J.S. 2006. Fishes of the World. Fourth Edition. John Wiley and Sons, Inc. Toronto, pp. 1-601.

Noubhani, A., and Cappetta, H. 1997. Les Orectolobiformes, Carcharhiniformes et Myliobatiformes (Elasmobranchii, Neoselachii) des Bassins à phosphate du Maroc (Maastrichtien-Lutétien basal). Systématique, biostratigraphie, évolution et dynamique des faunes. Palaeo Ichthyologica, 8: 1-327.

Otero, R.A. and Soto-Acuña, S. 2015. New chondrichthyans from Bartonian-Priabonian levels of Río de Las Minas and Sierra Dorotea, Magallanes Basin, Chilean Patagonia. Andean Geology, 42: 268-283.

Padilla, A., Eberle, J.J., Gottfried, M.D., Sweet, A.R., Hutchison, J.H. 2014. A Sand Tiger Shark-Dominated Fauna from the Eocene Arctic Greenhouse. Journal of Vertebrate Paleontology, 34: 1307-1316.

Parmley, D., and Cicimurri, D.J. 2003. Late Eocene sharks of the Hardie Mine local fauna of Wilkinson County, Georgia. Georgia Journal of Science, 61: 153-179. 
Pledge, N.S. 1967. Fossil Elasmobranch teeth of South Australia and their stratigraphic distribution. Transaction of the Royal Society of South Australia, 91: 135-160

Reif, W. 1976. Morphogenesis, pattern formation and function of the dentition of Heterodontus (Selachii). Zoomorphology, 83: 1-47.

Rüppell, W.P.E.S.E. 1837. Neue Wirbelthiere zu der Fauna von Abyssinien gehorig. Fische des Rothen Meeres, part 2. Frankfurt am Main (Siegmund Schmerber). pp. 53-80.

Smith, A. 1828. Descriptions of new, or imperfectly known objects of the animal kingdom, found in the south of Africa. South African Commercial Advertiser, 3: 2

Siverson, M. 1995. Revision of the Danian Cow Sharks, Sand Tiger Sharks, and Goblin Sharks (Hexanchidae, Odontaspididae, and Mitsukurinidae) from Southern Sweden, Journal of Vertebrate Paleontology, 15: 1-12.

Springer, S. 1967. Social organization of shark populations. In Sharks, Skates and Rays. Edited by P.W. Gibert, R.F. Matheson, and D.P. Rall. Johns Hopkins University Press, Baltimore, pp.149-174.

Tabuce, R., Adnet, S., Cappetta, H., Noubhani, A., and Quillevere, F. 2005. Aznag (bassin d'Ouarzazate, Maroc), nouvelle localité à sélaciens et mammifères de l'Eocène moyen (Lutétien) d'Afrique. Bulletin de la Société géologique de France, 176: 381-400.

Underwood, C.J., Ward, D.J., King, C., Antar, S.M., Zalmout, I.S., and Gingerich, P.D. 2011. Shark and ray faunas in the middle and late Eocene of the Fayum area, Egypt. Proceedings of the Geologists' Association, 122: 47-66. 
Ward, D.J., and Wiest, R.L. 1990. A checklist of Palaeocene and Eocene sharks and rays (Chondrichthyes) from the Pamunkey Group, Maryland and Virginia, USA. Tertiary Research, 12: 81-88.

Weems, R.E., and Bybell, L.M. 1998. Geology of the Black Mingo Group (Paleocene) in the Kingstree and St. Stephen areas of South Carolina. In Paleobiology of the Williamsburg Formation (Black Mingo Group; Paleocene) of South Carolina, U.S.A. Edited by A.E. Sanders. Transactions of the American Philosophical Society. pp. 9-27.

Weems, R.E. 1999. Actinopterygian fishes from the Fisher/Sullivan Site. In Early Eocene vertebrates and plants from the Fisher/Sullivan site (Nanjemoy Formation) Stafford County, Virginia. Edited by R.E. Weems and G.J. Grimsley. Virginia Division of Mineral Resources Publication. pp. 53-99.

Weems, R.E., and Grimsley, G.J. 1999. Introduction, geology, and paleogeographic setting. In Early Eocene vertebrates and plants from the Fisher/ Sullivan site (Nanjemoy Formation) Stafford County, Virginia. Edited by R.E. Weems and G.J. Grimsley. Virginia Division of Mineral Resources Publication. pp. 1-10.

Westgate, J.W. 1989. Lower vertebrates from an estuarine facies of the middle Eocene Laredo Formation (Claiborne Group), Webb County, Texas. Journal of Vertebrate Paleontology, 9: 282-294.

Willoughby, R.H., Nystrom, Jr., P.G., Campbell, L.D., and Katuna, M.P. 1999. Cenozoic stratigraphic column for the coastal plain of South Carolina. Columbia, South Carolina: South Carolina Geologic Survey, General Geologic Chart 1. 
White, E.I. 1931. The vertebrate faunas of the English Eocene. I. From the Thanet Sands to the Basement Bed of the London Clay. British Museum (Natural History). pp. $1-121$.

White, E.I. 1934. Fossil fishes of Sokoto province. Bulletin of the Geological Survey of Nigeria, 14: 1-78.

Winkler, T.C. 1874. Mémoire sur des dents de poissons du terrain bruxellien. Archives du Musée Teyler, 3: 295-304.

Winkler, T.C. 1876. Mémoire sur quelques restes de poisons du système heersien. Archives du Musée Teyler, 4: 1-15.

Woodward, A.S. 1888. Notes on the determination of the fossil teeth of Myliobatis, with a revision of the English Eocene species. Annals and Magazine of Natural History (Series 6), 1: 36-47.

Woodward, A.S. 1889. Catalogue of the Fossil Fishes in the British Museum. Part. I. British Museum (Natural History), pp. 1-474.

Zhelezko, V.I., and Kozlov, V.A. 1999.Elasmobranhii i biostratigraphia paleogena Zauralia i Srednei Asii. (Elasmobranchii and Palaeogene biostratigraphy of Transural and Central Asia). Materialy po stratigrafii i paleontologii Urala, 3. pp. $1-324$. 


\section{Figure captions}

Fig. 1. Map of eastern South Carolina, U.S.A., showing the locations of Paleogene localities, including the early Eocene (Ypresian) locality near Jamestown, Berkeley County (arrow), the late Oligocene locality at Summerville (empty square), and the Paleocene localities at St. Stephens and Kingstree (solid squares), together with late Paleocene through middle Eocene stratigraphy of the Lower Coastal Plain in and near Berkeley County, northeastern South Carolina, USA. The early Eocene Fishburne Formation unconformably overlies Paleocene sandstones of the Williamsburg Formation and uncomformably underlies middle Eocene limestones of the Moultrie Member of the Santee Formation. Calcareous Nannofossil Zones (NP Zones) were determined by Edwards et al. (2000) from well cores in nearby Dorchester County. Silhouettes of shark teeth represent fossil occurrence within the upper layers of the Fishburne Formation.

Fig. 2. Selachian teeth recovered from the early Eocene Fishbourne Formation at the Jamestown location. (1A-D) Squatina sp., complete lateral tooth, UALVP 55670; (2A-C) Heterodontus cf. sowasheense Case, 1994, fractured anterior tooth, UALVP 55671; (3A, B) H. cf. sowasheense, complete lateral tooth, UALVP 55672; (4A, B) Heterodontus sp., fractured lateral tooth, UALVP 55673; (5A, B) Nebrius thielensis (Winkler, 1874), fractured anterolateral tooth, UALVP 55674; (6A, B) N. thielensis, fractured lateral tooth, UALVP 55675. Views: labial (left), profile (center), lingual (right), basal (bottom) for 1; labial (left), profile (center), lingual (right) for 2; occlusal (top), lingual (bottom) for 3 and 4; labial (left), lingual (right) for 5 and 6. Scale bars $=1 \mathrm{~mm}$. 
Fig. 3. Additional selachian teeth recovered from the early Eocene Fishbourne Formation at the Jamestown location. (1A-D) Protoginglymostoma ypresiensis Herman, 1977b, slightly fractured tooth, UALVP 55676; (2A-D) Hemiscyllium aff. bruxelliensis Herman, 1977b, slightly fractured tooth, UALVP 55677; (3A-C) H. aff. bruxelliensis, fractured tooth, UALVP 55678; (4A-C) Palaeorhincodon sp. fractured tooth, UALVP 55679. Views: labial (left), profile (left center), lingual (right center), basal (right) for 1 and 2; labial (left), profile (center), lingual (right) for 3 and 4 . Scale bars $=1 \mathrm{~mm}$.

Fig. 4. Additional selachian teeth recovered from the early Eocene Fishbourne Formation at the Jamestown location. (1A, B) Brachycarcharias mississippiensis (Case, 1994), fractured anterior tooth, UALVP 55680; (2A, B) B. mississippiensis, complete lateral tooth, UALVP 55681; (3A, B) Striatolamia macrota (Agassiz, 1843), complete anterior tooth, UALVP 55682; (4A-C) S. macrota, slightly fractured lateral tooth, UALVP 55683; (5A, B) S. macrota, complete lateral tooth, UALVP 55684; (6A-C) S. macrota, slightly fractured anterior tooth, UALVP 55685; (7A, B) Anomotodon sp., slightly fractured lateral tooth, UALVP 55686. Views: labial (left), lingual (right) for 1, 2, 3, and 5; labial (left), profile (center), lingual (right) for 4 and 6; labial (top), lingual (bottom) for 7. Scale bars $=1 \mathrm{~mm}$.

Fig. 5. Additional selachian teeth recovered from the early Eocene Fishbourne Formation at the Jamestown location. (1A-C) Premontreia subulidens (Arambourg, 1952), complete anterior tooth, UALVP 55687; (2A, B) Pachygaleus lefevrei (Daimeries, 1891), fractured 
lateral tooth, UALVP 55688; (3A, B) P. lefevrei, complete lateral tooth, UALVP 55689; (4A, B) Abdounia beaugei (Arambourg, 1935), complete anterior tooth, UALVP 55690; (5A, B) A. beaugei, complete anterolateral tooth, UALVP 55691; (6A, B) Physogaleus secundus (Agassiz, 1843), complete lateral tooth, UALVP 55692; (7A, B) P. secundus, fractured anterolateral tooth, UALVP 55693. Views: labial (left), profile (center), lingual (right) for 1; labial (top), lingual (bottom) for 2; labial (left), lingual (right) for 3, 4, 5, 6, and 7. Scale bars $=1 \mathrm{~mm}$.

Fig. 6. Batomorph teeth recovered from the early Eocene Fishbourne Formation at the Jamestown location. (1A-D) Rhinobatos sp., complete tooth, UALVP 55694; (2A-C) Eotorpedo hilgendorfi (Jaekel, 1904), complete lateral tooth, UALVP 55695; (3A-C) Jacquhermania duponti (Winkler, 1874), complete anterior tooth, UALVP 55696; (4AC) J. duponti, complete lateral tooth, UALVP 55697; (5A, B) Meridiania convexa Case, 1994, complete median tooth, UALVP 55698; (6A-C) M. convexa, complete median tooth, UALVP 55699. Views: occlusal (left), labial (left center), profile (right center), lingual (right) for 1; labial (top), profile (center), lingual (bottom) for 2; labial (left), profile (center), lingual (right) for 3 and 4; occlusal (top), labial (bottom) for 5; occlusal (left), profile (center), lingual (right) for 6. Scale bars $=1 \mathrm{~mm}$.

Fig. 7. Additional batomorph teeth recovered from the early Eocene Fishbourne Formation at the Jamestown location. (1A-C) Myliobatis sp., complete median tooth, UALVP 55700; (2A-D) Burnhamia cf. daviesi (Woodward, 1889), complete median tooth, UALVP 55701; (3A-D) Hypolophodon dockeryi (Case, 1994), complete tooth, 
UALVP 55702; (4A-C) Coupatezia sp., complete tooth, UALVP 55703. Views: occlusal (left), labial (right), basal (bottom) for 1; occlusal (top), labial (left), profile (center), lingual (right) for 2; occlusal (top left), labial (top right), profile (bottom left), lingual (bottom right) for 3 and 4 . Scale bars $=1 \mathrm{~mm}$. 


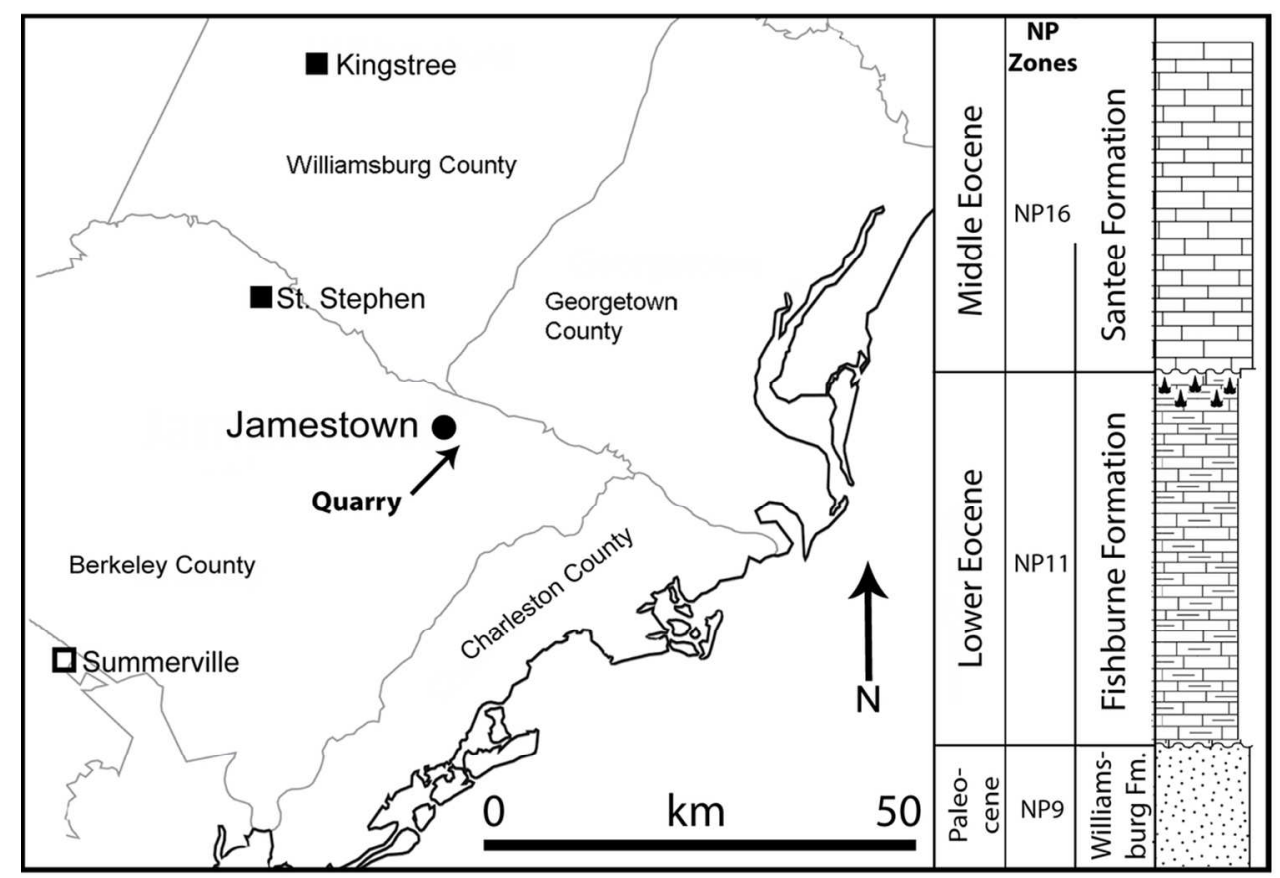

$106 \times 70 \mathrm{~mm}(300 \times 300 \mathrm{DPI})$ 


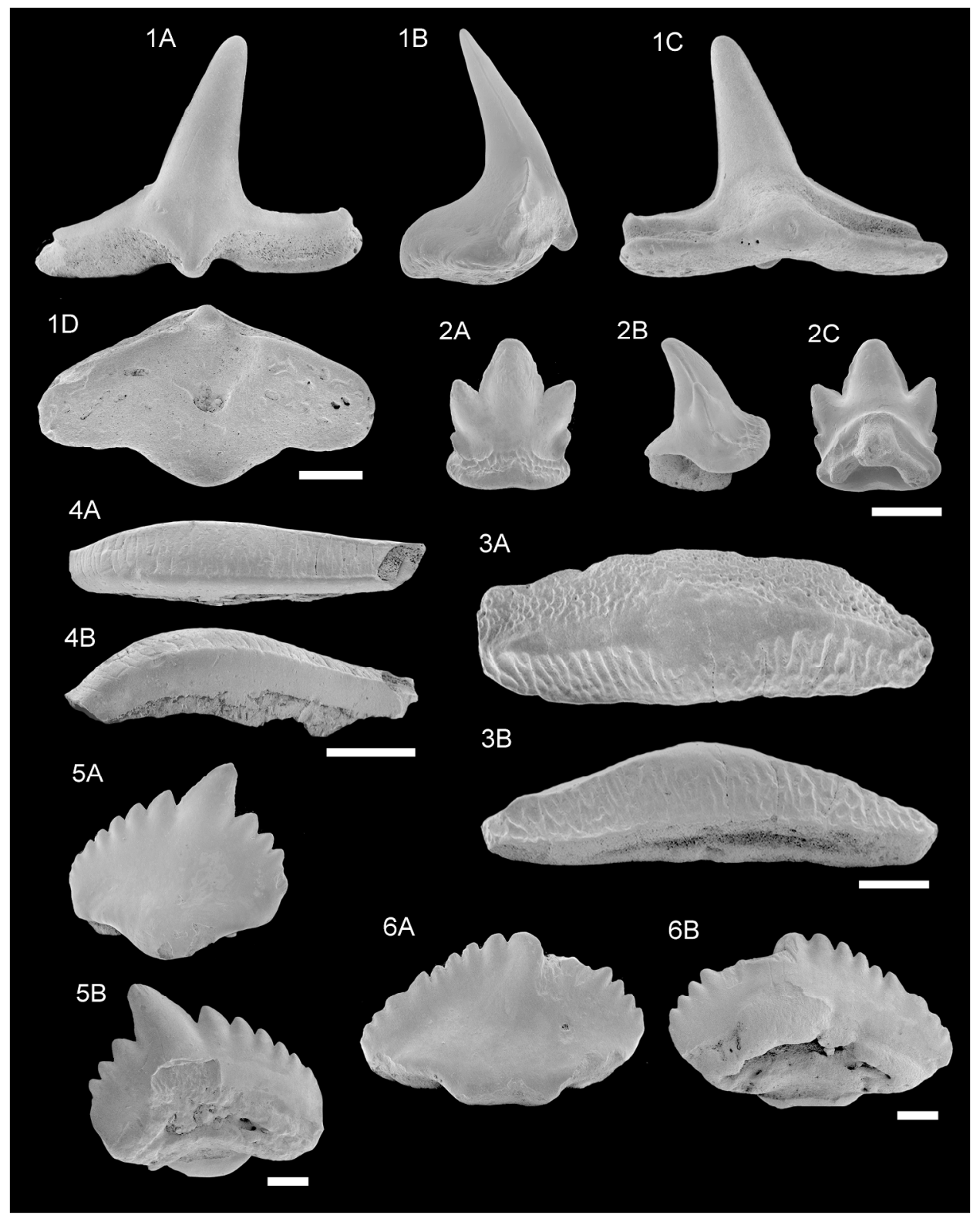

$229 \times 287 \mathrm{~mm}(300 \times 300 \mathrm{DPI})$ 


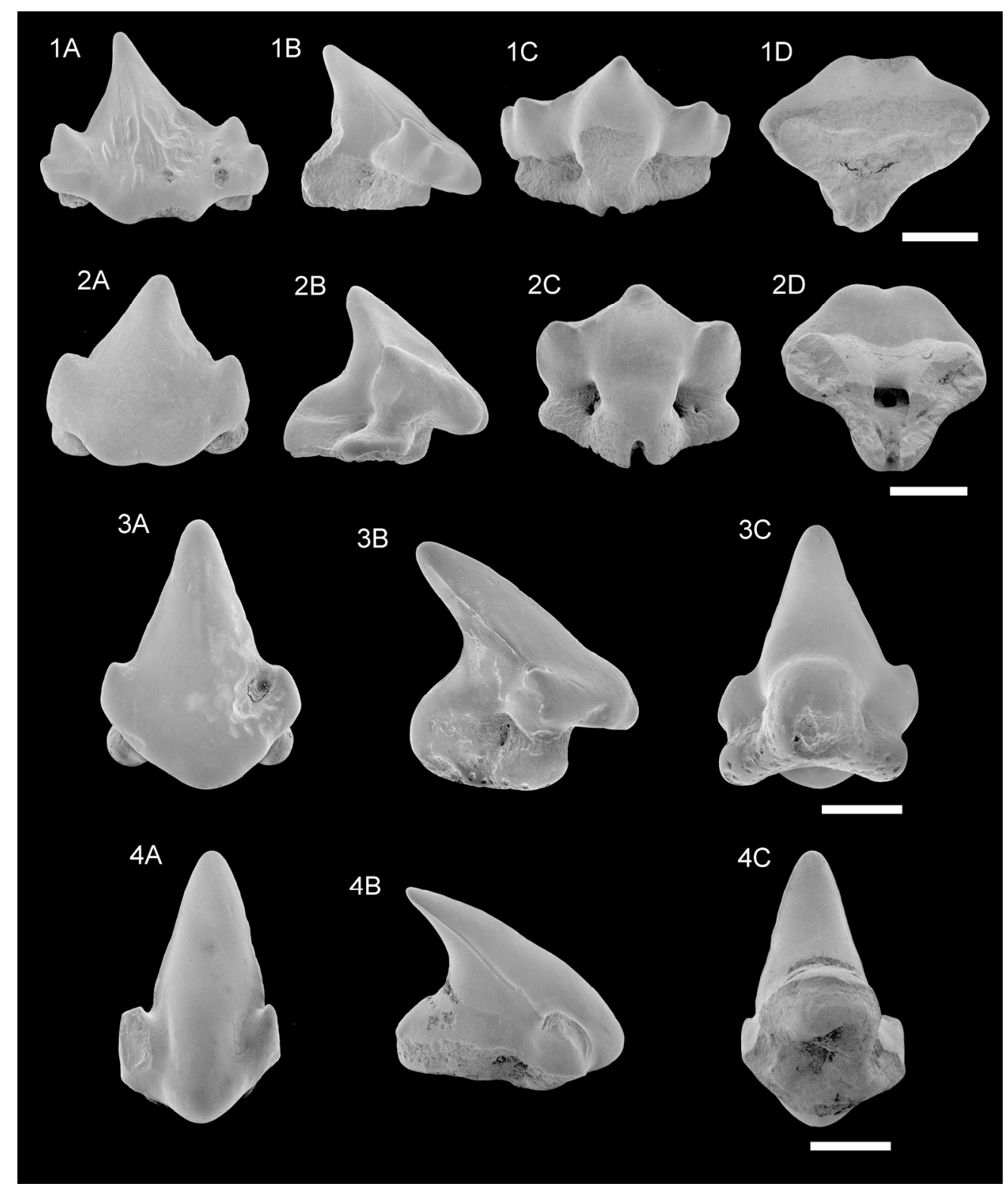

$217 \times 258 \mathrm{~mm}(300 \times 300 \mathrm{DPI})$ 


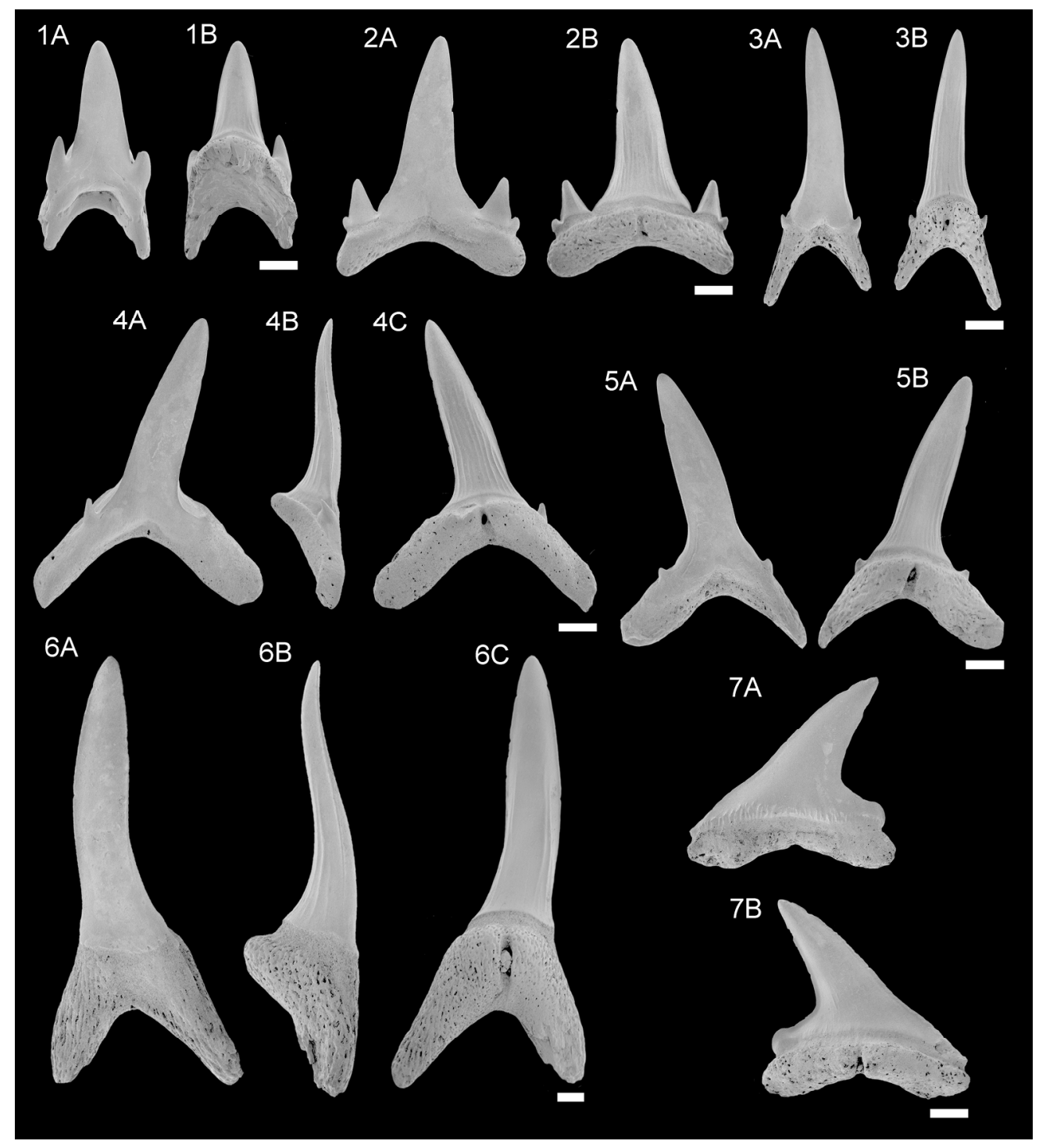

$203 \times 225 \mathrm{~mm}(300 \times 300$ DPI $)$ 


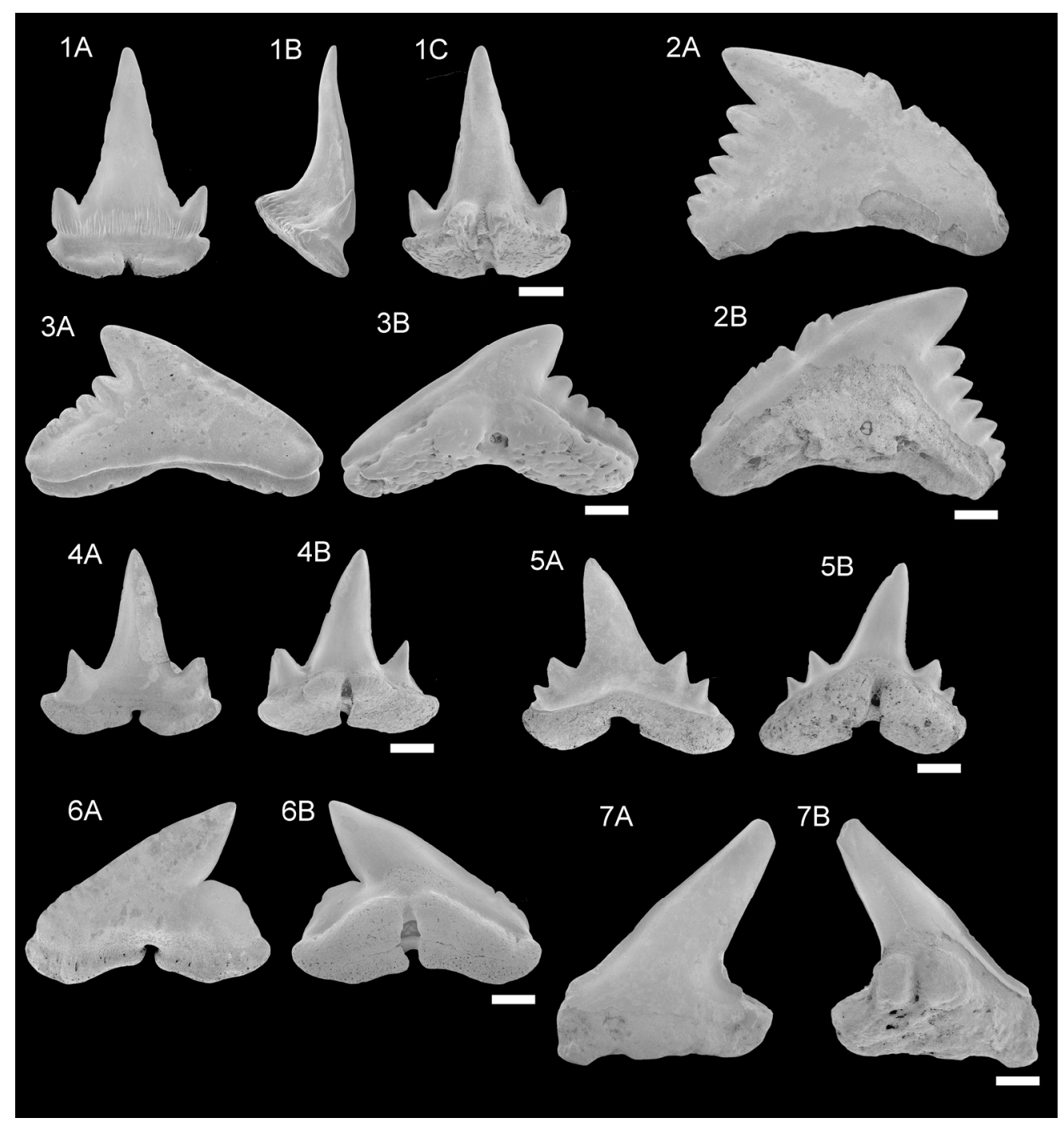

$193 \times 205 \mathrm{~mm}(300 \times 300 \mathrm{DPI})$ 


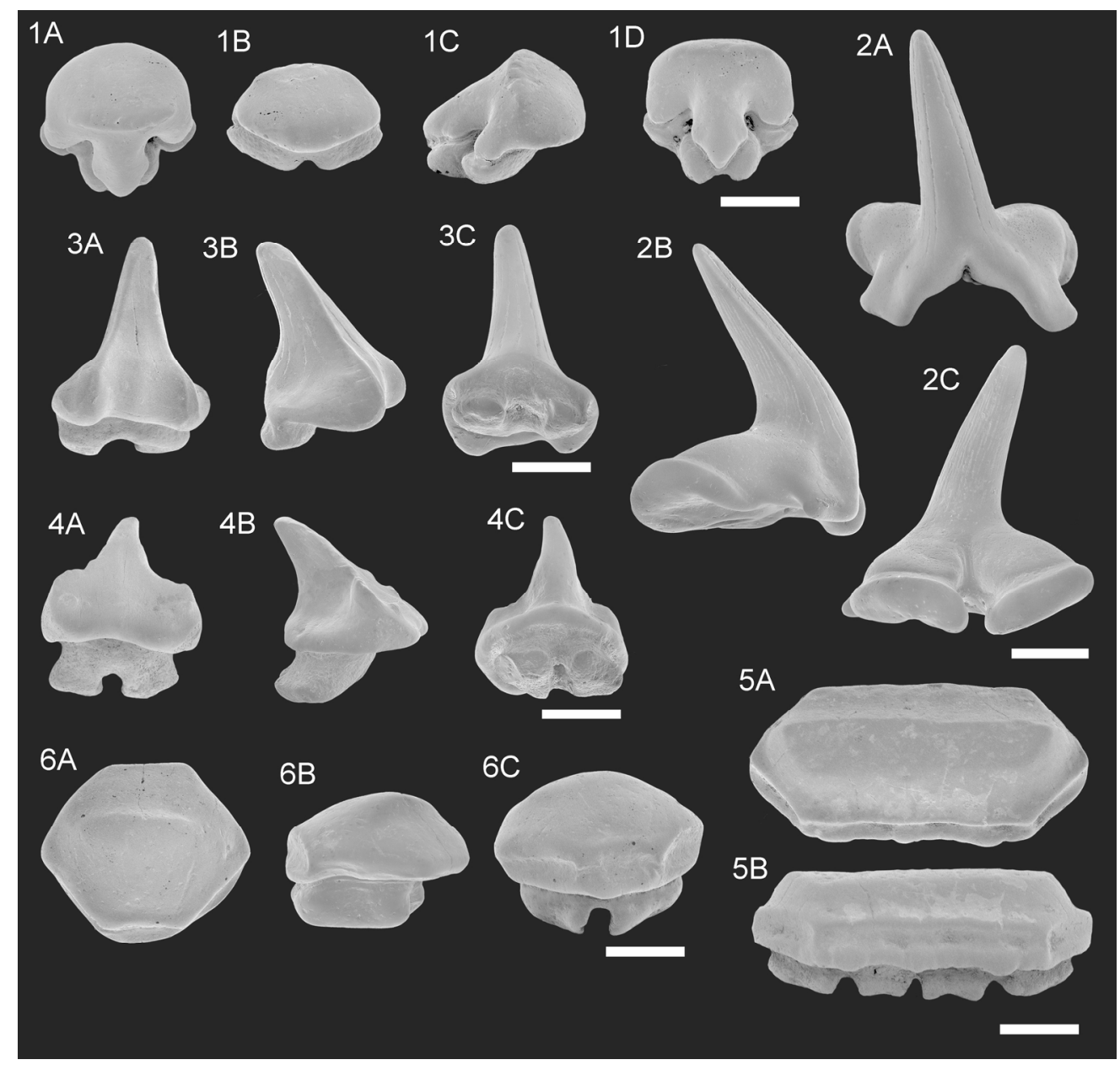

$171 \times 163 \mathrm{~mm}(300 \times 300 \mathrm{DPI})$ 


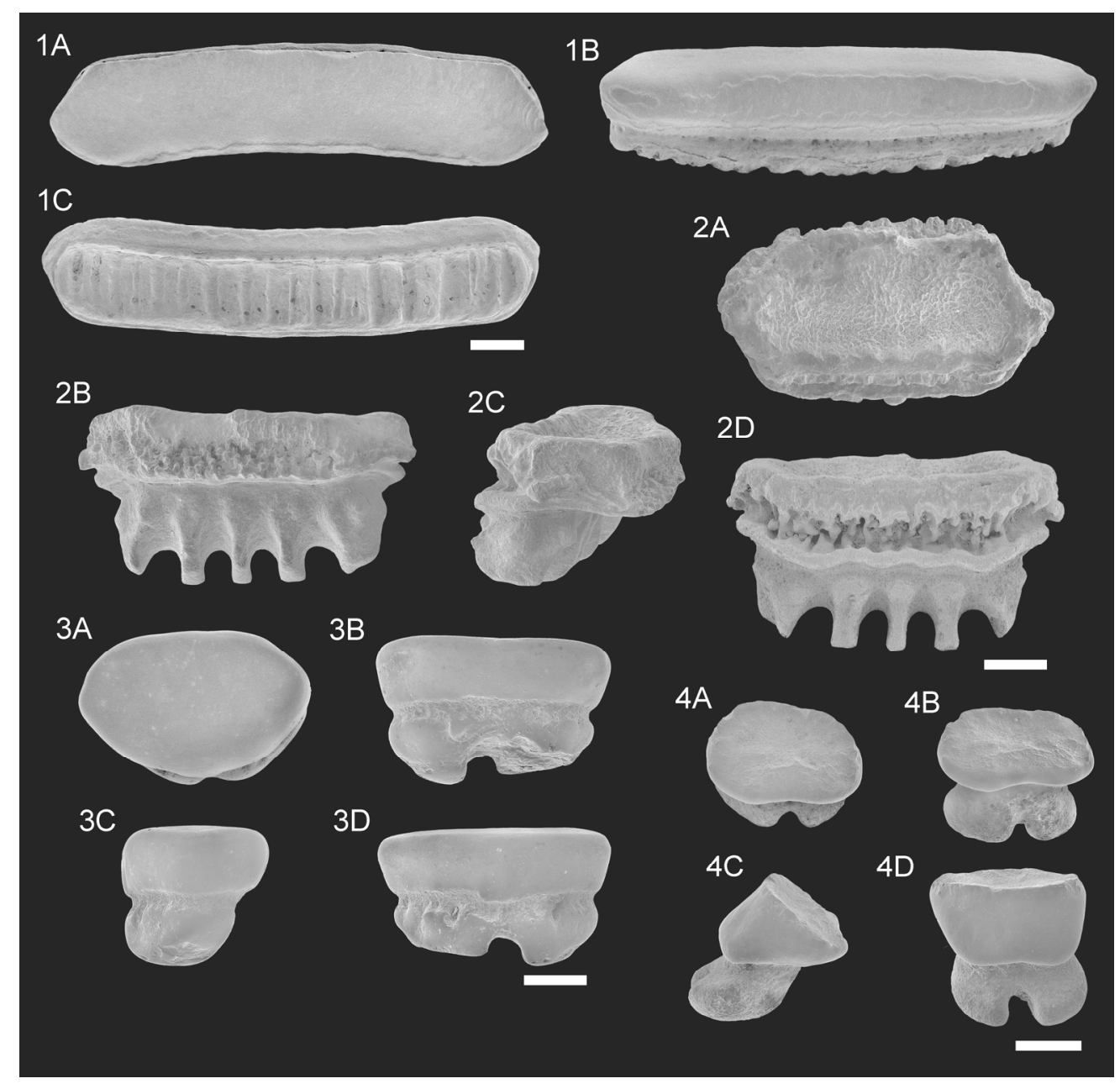

$174 \times 169 \mathrm{~mm}(300 \times 300$ DPI $)$ 
Table 1. Faunal comparison between the Jamestown assemblage and other early-middle Eocene assemblages from North America, Europe, central Asia, and northern Africa.

\begin{tabular}{|c|c|c|c|c|c|c|}
\hline $\begin{array}{l}\text { Jamestown taxa (number of } \\
\text { specimens collected) }\end{array}$ & $\begin{array}{l}\text { Mississippi } \\
\text { Gulf Coast }\end{array}$ & $\begin{array}{l}\text { Chesapeake } \\
\text { Bay region }\end{array}$ & $\begin{array}{l}\text { Northern } \\
\text { Canada }\end{array}$ & Europe & $\begin{array}{l}\text { central } \\
\text { Asia }\end{array}$ & $\begin{array}{l}\text { northern } \\
\text { Africa }\end{array}$ \\
\hline${ }^{1}$ Squatina sp. (6) & $?$ & $?$ & - & $?$ & $?$ & $?$ \\
\hline $\begin{array}{l}{ }^{2} \text { Heterodontus } \mathrm{cf} . \\
\text { sowasheense }(5)\end{array}$ & $?$ & - & - & - & - & - \\
\hline Heterodontus sp. (1) & - & - & - & - & - & - \\
\hline Nebrius thielensi (2) & $X$ & $X$ & - & $X$ & - & - \\
\hline $\begin{array}{l}\text { Protoginglymostoma } \\
\text { ypresiensis (3) }\end{array}$ & - & - & - & $X$ & - & $\mathrm{X}$ \\
\hline${ }^{3}$ Hemiscyllium sp. (3) & - & - & - & $?$ & - & - \\
\hline${ }^{4}$ Palaeorhincodon sp. (1) & - & - & - & - & - & $?$ \\
\hline $\begin{array}{l}{ }^{5} \text { Brachycarcharias } \\
\text { mississippiensis (2) }\end{array}$ & $\mathrm{X}$ & - & - & - & - & - \\
\hline${ }^{6}$ Striatolamia macrota (29) & $\mathrm{X}$ & $\mathrm{X}$ & $\mathrm{X}$ & $X$ & $X$ & $\mathrm{X}$ \\
\hline Anomotodon sp. (2) & $\mathrm{X}$ & - & - & - & - & - \\
\hline $\begin{array}{l}\text { Premontreia (Oxyscyllium) } \\
\text { gilberti }(285)\end{array}$ & $X$ & $X$ & - & $X$ & $\mathrm{X}$ & - \\
\hline Pachygaleus lefevrei (2) & $\mathrm{X}$ & $X$ & - & $\mathrm{X}$ & - & - \\
\hline Abdounia beaugei (168) & $\mathrm{X}$ & $X$ & - & $\mathrm{X}$ & $\mathrm{X}$ & $\mathrm{X}$ \\
\hline${ }^{7}$ Physogaleus secundus (18) & $X$ & $\mathrm{X}$ & $X$ & $X$ & - & $\mathrm{X}$ \\
\hline${ }^{8}$ Rhinobatos sp. (2) & $X$ & $?$ & - & $?$ & $?$ & $?$ \\
\hline${ }^{9}$ Eotorpedo hilgendorfi (8) & - & - & - & - & - & $\mathrm{X}$ \\
\hline Jacquhermania duponti (22) & $\mathrm{X}$ & $\mathrm{X}$ & - & $\mathrm{X}$ & - & - \\
\hline${ }^{10}$ Meridiania convexa $(1023)$ & $X$ & $\mathrm{X}$ & - & - & - & - \\
\hline${ }^{11}$ Myliobatis sp. (18) & $?$ & $?$ & $?$ & $?$ & $?$ & $?$ \\
\hline${ }^{12}$ Burnhamia aff. davisei (15) & $?$ & $?$ & - & $?$ & $?$ & - \\
\hline
\end{tabular}




\begin{tabular}{|l|c|c|c|c|c|c|}
\hline Hypolophodon dockeryi (3) & $\mathrm{X}$ & - & - & - & - & - \\
\hline${ }^{13}$ Coupatezia sp. (175) & - & - & - & - & - & $?$ \\
\hline
\end{tabular}

Note: "X" indicates occurrence of species; "?" indicates possible occurrence of species.

Refer to main text for references regarding North American, European, central Asian, and northern African assemblages.

${ }^{1}$ Tooth has an overall morphology similar to teeth reported as Squatina prima or $S$. cf. prima.

${ }^{2}$ Tooth an overall morphology similar to teeth reported as Heterodontus sowasheense.

${ }^{3}$ Tooth has an overall morphology similar to that of Hemiscyllium bruxelliensis.

${ }^{4}$ Tooth is damaged but is somewhat morphologically similar to that of Palaeorhincodon dartevellei.

${ }^{5}$ Species considered synonymous with Brachycarcharias lerichei by Cappetta (2006).

${ }^{6}$ Species also reported from Australia, South America, and Antarctica.

${ }^{7}$ Species also reported from south Asia.

${ }^{8}$ Identification to species is difficult due to the conservative nature of tooth morphology.

${ }^{9}$ Species also reported from western Africa.

${ }^{10}$ Species also reported from eastern Texas.

${ }^{11}$ Tooth has an overall morphology somewhat similar to teeth described as Myliobatis dixoni.

${ }^{12}$ Tooth has an overall morphology similar to teeth described as Burnhamia davisei.

${ }^{13}$ Tooth has an overall morphology similar to teeth described as Coupatezia boujoi. 